\title{
Trend analysis of evapotranspiration over India: Observed from long-term satellite measurements
}

\author{
Sheshakumar Goroshi ${ }^{1, *}$, Rohit Pradhan ${ }^{1}$, Raghavendra P Singh ${ }^{1}$, \\ K K Singh ${ }^{2}$ and JAI Singh PARIHAR ${ }^{1}$ \\ ${ }^{1}$ Space Applications Centre (ISRO), Ahmedabad 380 015, India. \\ ${ }^{2}$ India Meteorological Department, New Delhi 110 003, India. \\ *Corresponding author.e-mail: S.Goroshi@cgiar.org
}

MS received 24 January 2017; revised 12 May 2017; accepted 25 May 2017; published online 23 November 2017

Owing to the lack of consistent spatial time series data on actual evapotranspiration (ET), very few studies have been conducted on the long-term trend and variability in ET at a national scale over the Indian subcontinent. The present study uses biome specific ET data derived from NOAA satellite's advanced very high resolution radiometer to investigate the trends and variability in ET over India from 1983 to 2006. Trend analysis using the non-parametric Mann-Kendall test showed that the domain average ET decreased during the period at a rate of $0.22 \mathrm{~mm} \mathrm{year}^{-1}$. A strong decreasing trend $\left(m=-1.75 \mathrm{~mm}\right.$ year $\left.{ }^{-1}, F=17.41, P<0.01\right)$ was observed in forest regions. Seasonal analyses indicated a decreasing trend during southwest summer monsoon $\left(m=-0.320 \mathrm{~mm}\right.$ season $^{-1}$ year $\left.^{-1}\right)$ and post-monsoon period $\left(m=-0.188 \mathrm{~mm}\right.$ season $^{-1}$ year $\left.^{-1}\right)$. In contrast, an increasing trend was observed during northeast winter monsoon $\left(m=0.156 \mathrm{~mm}_{\text {season }}{ }^{-1}\right.$ year $\left.^{-1}\right)$ and pre-monsoon $(m=$ $0.068 \mathrm{~mm} \mathrm{season}^{-1}$ year $^{-1}$ ) periods. Despite an overall net decline in the country, a considerable increase $\left(>4 \mathrm{~mm}_{\text {year }}{ }^{-1}\right.$ ) was observed over arid and semi-arid regions. Grid level correlation with various climatic parameters exhibited a strong positive correlation $(r>0.5)$ of ET with soil moisture and precipitation over semi-arid and arid regions, whereas a negative correlation $(r<-0.5)$ occurred with temperature and insolation in dry regions of western India. The results of this analysis are useful for understanding regional ET dynamics and its relationship with various climatic parameters over India. Future studies on the effects of ET changes on the hydrological cycle, carbon cycle, and energy partitioning are needed to account for the feedbacks to the climate.

Keywords. India; evapotranspiration; variability; climate change; NOAA AVHRR.

\section{Introduction}

Seasonal and inter-annual variability in actual evapotranspiration $(E T)$ plays a crucial role in influencing terrestrial hydrology, vegetation dynamics and energy partitioning of the land surface. Global ET consumes half of the solar radiation absorbed by the land surface (Trenberth et al. 2009) and returns more than $60 \%$ of the total precipitation on land to the atmosphere (Oki and Kanae 2006). Studies have reported that the temporal variability of climatic parameters has a profound impact on ET. Improved knowledge of ET dynamics and its relationship with climate 
variables is an important and major objective for projecting the future. Several biome specific and regional scale studies have been conducted across the world recognizing the importance of climate change and its impact on ET. However, very few studies have been carried out at a national scale. While it is important to know the response of ET to climate change on a national scale, it is also important to know the exact location within the country where increase/decrease occurred, when and why it occurred, and what are the vulnerable biome types. Several studies have been conducted to evaluate the trends of pan evaporation $\left(E T_{\mathrm{pan}}\right)$, potential evapotranspiration $\left(E T_{\mathrm{p}}\right)$ and actual evapotranspiration $(E T)$ in different regions of the world, along with trends of meteorological variables that govern the rates of $E T_{\text {pan }}$, $E T_{\mathrm{p}}$ and ET. Zhang et al. (2007) have discussed in detail the different evapotranspiration terms ('actual evapotranspiration' is the sum of evaporation from water and soil, and transpiration from the vegetation of a specific region; 'potential evapotranspiration' includes the maximum amount of water capable of being evaporated from the soil and transpired from the vegetation of a specific surface; and pan evaporation is the evaporation from open circular pans with a diameter of $20 \mathrm{~cm}$ ) and explained issues associated with the temporal trends of evapotranspiration, the pan evaporation contradiction, and the complimentary relationship theory.

In recent years, $E T_{\text {pan }}$ has figured in the climate change discussions (Bates et al. 2008). Studies on $E T_{\text {pan }}$ have reported both decreasing and increasing trend in different regions of the world since 1950s. Cohen et al. (2002) and da Silva (2004) have documented an increasing trend in $E T_{\text {pan }}$ over Israel and in north Brazil, while decreasing trends in $E T_{\text {pan }}$ were reported by Peterson et al. (1995) in the United states, Liu et al. (2004) in China, Roderick and Farquhar (2004) in Australia, and Tebakari et al. (2005) in Thailand. An investigation of trends in long-term potential evaporation for Oxford, England, showed an increasing trend (Burt and Shahgedanova 1998); however decreasing trends in $E T_{\mathrm{p}}$ have been documented by Moonen et al. (2002) for a site in Italy. Due to the contradictory results from studies of $E T_{\text {pan }}$ trends, there have been several efforts to show the apparent paradox between observed and expected trends in evaporation. The $E T_{\text {pan }}$ databased studies only give an idea of the possible trend of $E T$, nevertheless, implication of the trend in
$E T_{\text {pan }}$ on the trend in $E T$ has long been disputed. Some of the researchers contend that the decreasing trend in $E T_{\text {pan }}$ exhibits a decreasing trend in $E T$. While others suggest that a complimentary relationship exists between $E T_{\mathrm{p}}$ and $E T$, a decreasing trend in $E T_{\mathrm{p}}$ implying an increasing trend in ET (Ramírez et al. 2005). More recent studies have reported that these relationships qualify under certain conditions (Teuling et al. 2009; Yanjun et al. 2011). Evidently, the positive relationship occurs under conditions of sufficient water, while the complimentary relationship occurs under water-limited conditions.

India is known for its large variability of vegetation and climate. Rainfall and temperature variability have been historically considered the key causes for variability of ET in India. Although variability of temperature and rainfall is not a new phenomenon for the country, the variability has reportedly increased during the past few decades and has created severe water stresses in many parts of the country. Chattopadhyay and Hulme (1997) analyzed time series $E T_{\text {pan }}$ data for different stations in India, and for the country as a whole, for different seasons, both for shortterm (15 years) and long-term (32 years). The analysis showed a significant decreasing trend in both $E T_{\text {pan }}$ and $E T_{\mathrm{p}}$ over India. A similar longterm study over India by Padmakumari et al. (2013) using surface observations from 58 stations, reported a highly significant $(99.9 \%)$ decreasing trend in $E T_{\text {pan }}\left(9.24 \mathrm{~mm}_{\text {year }}{ }^{-1}\right)$ over the country. This constitutes $\sim 10 \%$ reduction of $E T_{\text {pan }}$ over the last four decades. The Asian summer monsoon shows a considerable spatial and inter-annual variation over the Indian landmass, which in turn creates spatio-temporal variations in land surface hydrothermal processes. Therefore, it is important to understand the relationship between ET and precipitation on the local scale. So far in India, studies have not been conducted to evaluate current trends in ET and the possible link of climate change with anthropogenic activities by investigating the trends in different climatic parameters, particularly precipitation, temperature, soil moisture and insolation. Although some short term studies have documented (Mallick et al. 2007; Bhattacharya et al. 2010) the spatial variability of $E T$ over agricultural crops in India, they have not demonstrated the response of $E T$ to climate variability. Little is known about the dynamics of ET and its response to climate change in India over the past three decades, making it extremely important 
to carry out studies on ET dynamics in relation to climatic parameters at a national scale.

A useful way to detect the response of ET to climate variability accurately is by using groundbased ET observations. However, due to limited spatial representation by ground observations and relatively sparse ground observation network in India, it is very difficult to upscale it for understanding ET dynamics at a national scale. Considerable efforts have been made all over the world to understand ET dynamics using weather data driven approach, soil moisture measurements, and surface energy balance methods. These approaches provide relatively precise $E T$ estimates, but require a substantial amount of soil, vegetation and climate related data. Use of satellite data derived land surface products like leaf area index (LAI), vegetation index (VI), albedo, land surface temperature (LST), and emissivity in climate change studies has considerably increased due to availability of consistent time series data. Among all the land surface products; VI is useful for longterm monitoring of the land surface and climate related processes. Global record of normalized difference vegetation index (NDVI) data since 1981 from the NOAA advanced very high resolution radiometer (AVHRR) is one of the widely-used time series satellite data for monitoring terrestrial vegetation and related land processes. Several recent studies have used the data for determining trends and variability in various key biophysical parameters all over the world (Bala et al. 2013; Goroshi et al. 2015; Marshall et al. 2016; Militino et al. 2017).

To improve the understanding of ET dynamics and response to climate change over India, the current study aimed to investigate trends and variability of ET over India and its relation with various climatic parameters covering the period 1983-2006. Specifically, this paper reports on: (1) the capability of NOAA derived time series monthly ET data to detect seasonal and interannual variability of $E T$ across India by comparing with lysimeter ET observations; (2) examination of variations in spatio-temporal $E T$ dynamics in the country over a period of 24 years; (3) identification of the relative contribution of climate variables to ET dynamics throughout the observation period. Results on $E T$ variation with vegetation types and their response to climate variables and explanation of spatial variation in potential climatic controls of evapotranspiration are also discussed.

\section{Study area}

The study area (India) with a total geographical area of 329 million hectares is situated in the tropics $\left(6^{\circ}-38^{\circ} \mathrm{N} ; 68^{\circ}-98^{\circ} \mathrm{E}\right)$. The country is known for its diverse vegetation and ecosystems (figure 1) and climatic variability. The climate is characterized by four different seasons in a year: winter season (January-February), pre-monsoon season (March-May), southwest monsoon season (JuneSeptember) and post-monsoon season (northeast monsoon period, October-December). The southwest monsoon period is warm and humid, and the rainfall received during this period accounts for $80 \%$ of the total annual rainfall in the country. Northeast monsoon period is cold and dry; however southeastern parts of the country receive significant amount of rainfall during this period. The two inter-monsoonal periods are mostly dry and moderately warm. Annual mean temperature varies with latitude, ranging from $25^{\circ} \mathrm{C}$ in the humid regions to $45^{\circ} \mathrm{C}$ in arid regions. The vegetation across the country shows latitudinal zonation as a result of climate variation. Most vegetation types of humid and sub-humid regions, such as evergreen broadleaf forest, mixed forest and grasslands are predominant in the country. Arid and semi-arid regions are covered with short statured forest, meadow, shrub, and desert steppe.

The country includes 29 states and 7 union territories. The states and territories are further subdivided into districts (zilla), numbering 686 as of 2016. India is the second most populous country in the world with 1.34 billion people. Over $70 \%$ of the rural households depend on agriculture as their principal means of livelihood. Recent long-term studies on vegetation estimated increasing trend in agricultural net primary productivity, particularly in arid and semi-arid regions of the country over the past 25 years (Singh et al. 2011; Bala et al. 2013; Nayak et al. 2013).

This positive trend has been attributed to developments in agriculture such as increase in irrigated area under canal command, increased frequency and amount of irrigation, increased ground water pumping, increase in cropping intensity and change in cultivars (Gholkar et al. 2014). Large variability in rainfall and recent developments in arid and semi-arid regions provide a unique near-natural condition for studying the dynamics of land evapotranspiration and its response to climate change over India at a national scale. 


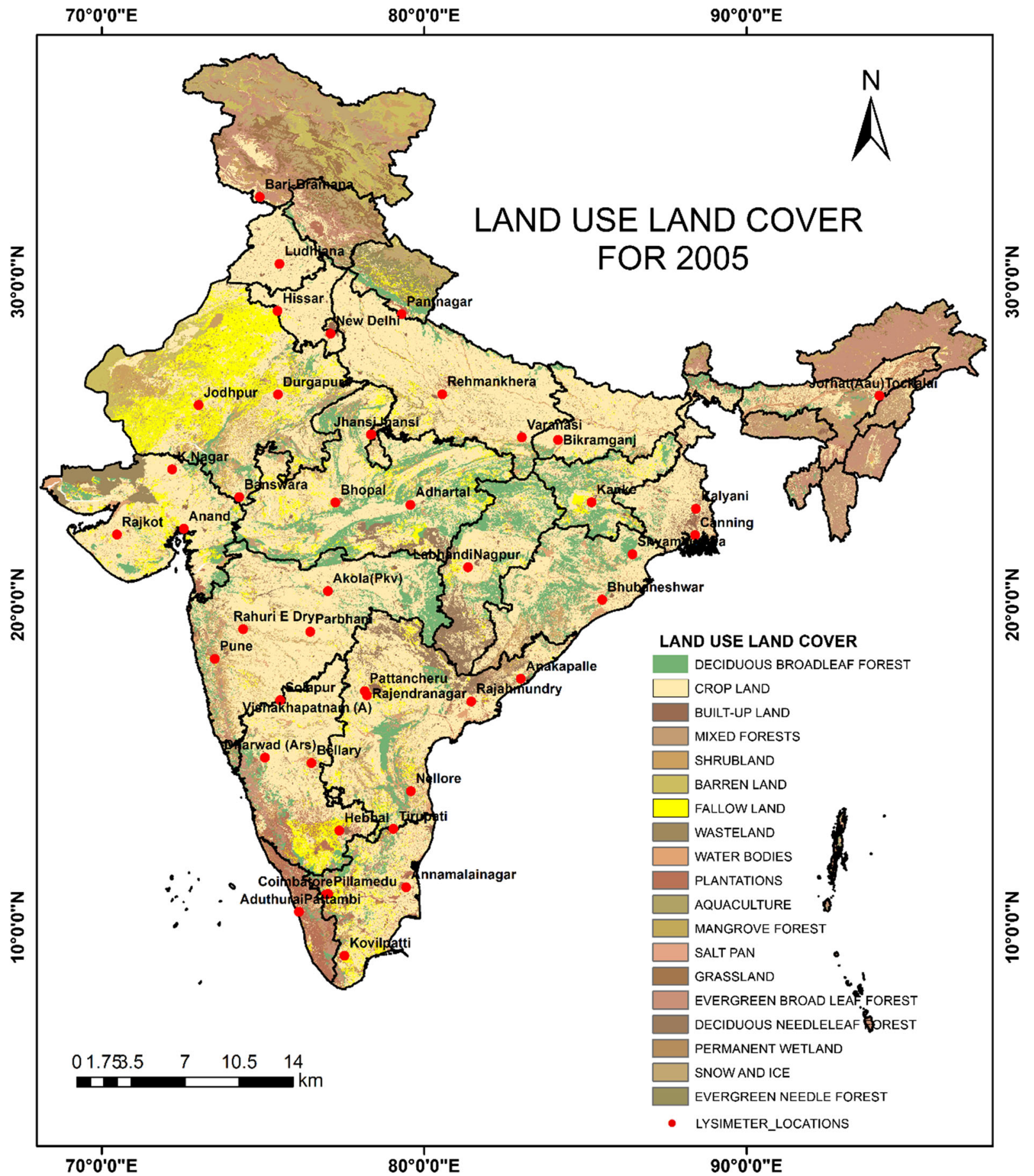

Figure 1. Land use land cover types derived for 2005 (Roy et al. 2015; Meiyappan et al. 2016). Red circles indicate lysimeter locations in crop lands across India.

\section{Data and algorithm}

\subsection{Satellite evapotranspiration data}

Long-term monthly (1983-2006) terrestrial ET product gridded at $8 \mathrm{~km} \times 8 \mathrm{~km}$ spatial resolution was acquired from numerical terradynamic simulation group (NTSG), The University of Montana. This product was generated by Zhang et al. (2010) using a satellite data driven ET algorithm. The algorithm estimates $E T$ ( $\left.E T_{\text {total }}\right)$ as sum of transpiration from canopy $\left(\lambda E_{\text {Canopy }}\right)$, evaporation from open water $\left(\lambda E_{\text {Water }}\right)$ and evaporation from soil $\left(\lambda \mathrm{E}_{\text {Soil }}\right)$ : 


$$
\mathrm{ET}_{\text {total }}=\lambda \mathrm{E}_{\text {Canopy }}+\lambda \mathrm{E}_{\text {Water }}+\lambda \mathrm{E}_{\text {Soil }} .
$$

The algorithm quantifies canopy transpiration using a modified Penman-Monteith approach (Monteith 1965) as:

$$
\lambda E_{\text {Canopy }}=\frac{\Delta A_{\text {Canopy }}+\rho C_{p}\left(e_{\text {sat }}-e\right) / r_{a}}{\Delta+\gamma\left(1+r_{s} / r_{a}\right)}
$$

where $\lambda \mathrm{E}_{\text {Canopy }}\left(\mathrm{W} \mathrm{m}^{-2}\right)$ is the latent heat flux of canopy (i.e., $\left.\mathrm{LE}_{\text {Canopy }}\right)$ and $\lambda\left(\mathrm{J} \mathrm{kg}^{-1}\right)$ is the latent heat of vaporization; $E$ is evaporation $(\mathrm{mm}), A$ term is available energy components for the canopy $\left(A_{\text {Canopy }}: \mathrm{W} \mathrm{m}^{-2}\right), \Delta=d\left(e_{\text {sat }}\right) / d T\left(\mathrm{~Pa} \mathrm{~K}^{-1}\right)$ and is the slope of the curve relating saturated water vapor pressure $\left(e_{\mathrm{sat}}: \mathrm{Pa}\right)$ to air temperature $(T: \mathrm{K})$; $e(\mathrm{~Pa})$ is the actual air water vapour pressure, so $e_{\mathrm{sat}}-e=\mathrm{VPD}$, where $\operatorname{VPD}(\mathrm{Pa})$ is the vapour pressure deficit; $\rho\left(\mathrm{kg} \mathrm{m}^{-3}\right)$ is the air density; $C_{p}\left(\mathrm{~J} \mathrm{~kg}^{-1} \mathrm{~K}^{-1}\right)$ is the specific heat capacity of air; $r_{a}\left(\mathrm{~s} \mathrm{~m}^{-1}\right)$ is the aerodynamic resistance and its reciprocal, $g_{a}\left(\mathrm{~m} \mathrm{~s}^{-1}\right)$ is the aerodynamic conductance. The psychometric constant is given by $\gamma=\left(M_{a} / M_{w}\right)\left(C_{p} P_{\text {air }} / \lambda\right)$, where $M_{a}\left(\mathrm{~kg} \mathrm{~mol}^{-1}\right)$, $M_{w}\left(\mathrm{~kg} \mathrm{~mol}^{-1}\right)$ and $P_{\text {air }}(\mathrm{Pa})$ are the molecular mass of dry air, the molecular mass of wet air, and the air pressure, respectively. The bulk surface resistance term $\left(r_{s}: \mathrm{s} \mathrm{m}^{-1}\right)$ is the effective resistance to canopy transpiration.

The algorithm determines open water evaporation using a Priestley-Taylor approach (Priestley and Taylor 1972):

$$
\lambda \mathrm{E}_{\text {Water }}=a \frac{\Delta A}{\Delta+\gamma}
$$

where the constant $a$ accounts for the evaporation arising from the humidity deficit in addition to the equilibrium term and is set to 1.26 following Priestley and Taylor (1972). Soil evaporation is estimated using the soil evaporation equation developed by $\mathrm{Mu}$ et al. (2007), which is the integration of a Penman-Monteith approach and the complementary relationship hypothesis (Bouchet 1963; Fisher et al. 2008).

$$
\lambda \mathrm{E}_{\text {Soil }}=R H^{(\mathrm{VPD} / k)} \frac{\Delta A_{\text {Soil }}+\rho C_{p} V P D / r_{a}}{\Delta+\gamma \cdot r_{\text {totc }} / r_{a}}
$$

$R H$ indicates relative humidity, $k(\mathrm{~Pa})$ is a parameter to establish a complimentary relationship and indicates the relative sensitivity to VPD (Fisher et al. 2008). To account the possible influence of various vegetation characteristics and their root zone arrangement among different vegetation types on this complimentary relationship, Zhang et al. (2010) empirically adjusted the $k$ parameter for different biome types. $r_{\text {totc }}\left(\mathrm{s} \mathrm{m}^{-1}\right)$ term is the corrected total aerodynamic resistance to vapour transport and the sum of surface and aerodynamic resistance components from the standard conditions for temperature and pressure (STP) using the correction coefficient (Jones 2013). For detailed description of the above terms, see Zhang et al. (2009). All these three equations (equations 2-4) were applied spatially using AVHRR global inventory modelling and mapping studies (GIMMS) NDVI records, NCEP/NCAR Reanalysis (NNR) daily surface meteorology and NASA/GEWEX Surface Radiation Budget (SRB) release-3.0 solar radiation inputs. Observations from FLUXNET towers were used to parameterize an NDVI-based canopy conductance model and then to validate the global ET algorithm. The analysis of the global ET results by Zhang et al. (2010) captures spatial and temporal variations in the global scale. It also compares favourably with ET inferred from basin-scale water balance calculations $(\mathrm{RMSE}=$ $186.3 \mathrm{~mm}$ year $\left.^{-1} ; R^{2}=0.80\right)$.

\subsection{Lysimeter ET data}

India Meteorological Department has 48 lysimeter in different soil and agro climatic zones of India (figure 1). The primary objective of this network was to assess precise water requirement of the crops at various growth stages. Most of these lysimeters are gravimetric type and daily $E T$ is recorded with an accuracy of about $0.12 \mathrm{~mm}$ of water. Earlier the data was used to compute water consumption and water use efficiency of different crops grown in various climatic zones (Datta 1993) in India. These daily records of $E T$ from 48 stations were used in this study to validate satellite derived monthly ET data over India from 1983 to 2006.

\subsection{Climate data}

Several climatic parameters affect the land evapotranspiration. The influence of some of the important parameters such as precipitation, air temperature, soil moisture and incident solar radiation on ET over India was studied in this analysis covering the period 1983-2006. A high spatial resolution daily gridded $\left(0.25^{\circ} \times 0.25^{\circ}\right.$, latitude $\times$ longi- 
tude) rainfall data product (IMD4) covering Indian subcontinent was acquired from India Meteorological Depertment (IMD) for the period 1983-2006. This product was developed based on 6995 rain gauge observations distributed across the country (Pai et al. 2014). Since the rain gauges used for developing this product are not uniformly distributed in space and time, IMD4 is belived to be a more realistic representative of measured rainfall data. In this product, climatological and variability features are well captured and orographic rainfall in heavy rainfall regions of the west coast and northeast, and low rainfall regions in the leeward side of the Western Ghats is represented realistically (Pai et al. 2014). IMD4 is arranged in $135 \times 129$ grid points which have been created by interpolating rain guage data. An extensively used Shepard's interpolation technique was employed to interpolate the gauge data into regular grids of 0.25 degree. After several comparsions and quality control efforts the product has been made available to user community. The dataset has been found to be useful for various regional applications in the country (Asoka and Mishra 2015; Duncan et al. 2016; Mishra and Lilhare 2016).

Another important climate dataset from IMD, daily gridded $\left(1^{\circ} \times 1^{\circ}\right.$, latitude $\times$ longitude $)$ mean temperature covering the Indian region was used in the analysis (Srivastava et al. 2009). The product was developed using temperature data from 395 quality controlled stations for the period 1969-2009. This product is arranged in $31 \times 31$ grid points, created by interpolating station data. A modified Shepard's angular distance weighting algorithm was adopted for interpolating the station temperature data into $1^{\circ}$ latitude $\times 1^{\circ}$ longitude grids. The dataset has been the focus of several studies in India (Prabakaran et al. 2013; Oza and Kishtawal 2015) to assess influence of temperature on various terrestrial bio-physicalbreak parameters.

Due to the lack of spatial long-term soil moisture and incoming shortwave radiation data over India, the following modelled soil moisture and shortwave radiation data were used in this analysis to ascertain the influence of soil moisture and radiation on ET dynamics over the country. Data on monthly mean soil moisture with global spatial coverage at $1 / 2^{\circ} \times 1 / 2^{\circ}$ resolution, reconstructed by Fan and van den Dool (2004) was obtained from NOAA's National Center for Environmental Prediction (NCEP), Climate Prediction Center (CPC) for the study period 1983-2006. The dataset was used in this analysis to determine influence of soil moisture on ET. The CPC soil moisture is calculated on a one-layer hydrological model (Huang et al. 1996; van den Dool et al. 2003) using observed rainfall and temperature. The rainfall data used in the model was derived from gauge observation from over 17,000 stations spread across the world and collected from the Global Historical Climatology Network (GHCN), version 2, and Climate Anomaly Monitoring System (CAMS) datasets using an ideal interpolation technique (Chen et al. 2002). The monthly tempertaure used in the model is a station observation-based global land monthly mean surafce air temperature developed recently at CPC, National Centres for Environmental Prediction (Fan and van den Dool 2008). CPC provides the water content at single soil vertical layer of depth $1.6 \mathrm{~m}$ having the maximum water holding capacity of $760 \mathrm{~mm}$ and a common porocity of 0.47. Testing and validation of CPC modelled soil moisture with in situ moisture measurements as well as with other global products showed a good agreement. The CPC soil moisture product has been used recently in India to determine reliabilityresilience-vulnerability (Chanda et al. 2014) and to assess its role on food grain yield and its variance (Prasanna 2014).

A monthly shortwave radiation product gridded at $1^{\circ} \times 1^{\circ}$, latitude $\times$ longitude was acquired over the study domain from the NASA/GEWEX Surface Radiation Budget (SRB) release-3.0. The product was derived using two sets of algorithms, known as primary and Langley parameterized algorithms, and number of inputs obtained from various sources. The primary algorithm is adapted from Pinker and Laszlo (1992) and Langley parameterized algorithm adopted from Gupta et al. (2001). SRB uses cloud properties derived from International Satellite Cloud Climatology Project (ISCCP) DX data and meteorological inputs from the GEOS version 4.0.3. The product was validated extensively using corresponding 5969 site months of ground based measurements from 52 Baseline Surface Radiation Network (BSRN) stations (Zhang et al. 2013). Results showed a good agreement between both the datasets with bias/RMS for the monthly mean shortwave fluxes of $-5.2 / 23.3$ $\mathrm{W} \mathrm{m}^{-2}$ under all sky conditions. Biggs et al. (2007) used an earlier version of (SRB release-2.0) incoming shortwave radiation product to study decadal trends in cloudiness, affecting incoming solar radiation in the Krishna River basin, southern India, from 1952 to 1997. 
Since there are no direct radiation observations over large continental region like India, high spatial resolution radiation products generated by integrating satellite-and ground-based observational products, and land surface models is considered a good way to evaluate the reliability of modelled radiation data over the region of interest. Such validation studies were carried out in East Asian region to validate satellite derived land surface products using Global Land Data Assimilation System (GLDAS) products (Velde et al. 2014; Xiao et al. 2016). The latest GLDAS, version-2 is producing high resolution, near real time land surface status and fluxes by assimilating satellite and ground-based observational data products, and land surface models and advanced data assimilating techniques (Fang et al. 2009; Rui and Beaudoing 2016). The NASA GES DISC maintains archives of all GLDAS data products (Rodell et al. 2004). Monthly mean soil moisture and downward shortwave radiation flux gridded at $0.25^{\circ} \times 0.25^{\circ}$, latitute $\times$ longitude, generated through temporal averaging of the reprocessed 3-hourly data, includes a series of land surface fields simulated from the Noah Model 3.3 were obtained over Indian subcontinent to evaluate reliability of modelled soil moisture acquired from $\mathrm{CPC}$ and shortwave radiation from SRB. The Noah Model 3.3 simulates depth-averaged soil moisture at four vertical layers (0-10, 10-40, 40-100 and 100-200 cm). Among these four soil depths, soil moisture simulated at fourth layer $(100-200 \mathrm{~cm})$ was used in this analysis to achieve a better soil depth match to compare with the soil moisture values obtained from CPC $(1.6 \mathrm{~m})$. Details of the data and their usage in this analysis are summarized in table 1 .

\subsection{Vegetation map}

An extensively validated decadal land use/land cover classification data across India for 1985, 1995 and 2005 were acquired from https://daac. ornl.gov/. The product was derived using Landsat 4 and 5 Thematic Mapper (TM), Enhanced Thematic Mapper Plus (ETM+), and Multispectral Scanner (MSS) data, Indian Remote Sensing Satellites (IRS) Resourcesat Linear Imaging SelfScanning Sensor-1 or III (LISS-I, LISS-III) data, ground truth surveys, and visual interpretation. The data were classified according to the International Geosphere-Biosphere Programme (IGBP) classification scheme. The scheme identifies 19 land cover classes based on different phenological patterns of the vegetation. Details of the product are given in Meiyappan et al. (2016) and Roy et al. (2015). This product was used in the study to extract biome specific ET values for the years, falling in the respective land cover decade. For instance, ET values from 1983 to 1989 were extracted using land cover 1985, likewise from 1990-1999 (1995) and 2000-2006 (2005), respectively. Further biome specific ET values were used to know their mean annual ET and trends in interannual variability of ET.

\section{Methods}

Satellite-derived ET and field-observed ET are on different scales and it is difficult to relate the two considering the propagation errors involved. A proper approach to overcome this problem remains a scientific challenge. However, field measured ET can still provide a basis for deriving ET from satellite data. With this understanding, satellite data derived monthly, seasonal and annual ET were validated in the study, using daily lysimeter $E T$ records obtained from 48 stations located in crop lands across India. Coefficient of determination $\left(R^{2}\right)$, root mean square error (RMSE) and Willmott's index of agreement (Willmott 1981, 1982) were employed to validate the satellite derived ET data. The Willmott's index of agreement $(d)$ is defined as:

$$
d=1-\frac{\sum_{i=1}^{n}\left(O_{i}-P_{i}\right)^{2}}{\sum_{i=1}^{n}\left(\left|O_{i}-\bar{O}\right|+\left|P_{i}-\bar{O}\right|\right)^{2}}
$$

where $O_{i}$ is observed value (lysimeter $\left.E T\right), P_{i}$ is the estimated value (satellite $E T$ ), $\bar{O}$ and $\bar{P}$ are mean of the observed and estimated ET values. A non-dimensional measure $(d)$ that ranges from 0 to 1 , wherein $d$ is equal to 1 when two datasets are in ideal agreement. In order to determine the influence of climate parameters on ET; precipitation, temperature, soil moisture and solar radiation products were obtained from IMD, CPC and SRB. Precipitation and temperature obtained from IMD have already proven their utility over India (Pingale et al. 2014; Oza and Kishtawal 2015). So far in India, very few studies have been conducted using the soil moisture data from $\mathrm{CPC}$ and insolation from SRB. Hence, first $\mathrm{CPC}$ and SRB products over India were validated using soil moisture and shortwave radiation flux data obtained from latest 
Table 1. Details of the data used in the present analysis.

\begin{tabular}{|c|c|c|c|c|}
\hline Sl. no. & Data & Period & Purpose & Source \\
\hline 1 & Satellite ET & 1983 to 2006 & $\begin{array}{l}\text { Investigate trend and } \\
\text { variability of } \mathrm{ET} \text { over } \\
\text { India }\end{array}$ & http://www.ntsg.umt.edu/ \\
\hline 2 & Lysimeter ET & 1983 to 2006 & $\begin{array}{l}\text { For validation of satellite } \\
\text { ET }\end{array}$ & http://www.imd.gov.in/ \\
\hline 3 & Land use land cover & 1985,1995 and 2005 & $\begin{array}{l}\text { Determine biome specific } \\
\text { ET values }\end{array}$ & https://daac.ornl.gov/ \\
\hline 4 & Precipitation & 1983 to 2006 & $\begin{array}{l}\text { Assess relationship with } \\
\text { ET }\end{array}$ & http://www.imd.gov.in/ \\
\hline 5 & Temperature & & & \\
\hline 6 & $\begin{array}{l}\text { Solar radiation } \\
\quad(\mathrm{SRB} \text { release- } 3.0)\end{array}$ & & $\begin{array}{l}\text { Assess relationship with } \\
\text { ET }\end{array}$ & https://eosweb.larc.nasa.gov \\
\hline 7 & $\begin{array}{l}\text { Solar radiation } \\
\quad(\text { GLDAS-version2) }\end{array}$ & & $\begin{array}{l}\text { For validation of solar } \\
\text { radiation obtained from } \\
\text { SRB }\end{array}$ & $\begin{array}{c}\text { https://disc.gsfc.nasa.gov/ } \\
\text { uui/datasets/GLDAS_ } \\
\text { NOAH025_M_V2.0/ }\end{array}$ \\
\hline 8 & $\begin{array}{l}\text { Soil moisture } \\
\text { (CPC-v2) }\end{array}$ & & $\begin{array}{l}\text { Assess relationship with } \\
\text { ET }\end{array}$ & $\begin{array}{l}\text { http://www.cpc.ncep.noaa. } \\
\text { gov/soilmst/leaky_glb.htm }\end{array}$ \\
\hline 9 & $\begin{array}{l}\text { Soil moisture } \\
\text { (GLDAS-version2) }\end{array}$ & & $\begin{array}{l}\text { For validation of soil } \\
\text { moisture obtained from } \\
\text { CPC }\end{array}$ & $\begin{array}{c}\text { https://disc.gsfc.nasa.gov/ } \\
\text { uui/datasets/GLDAS_ } \\
\text { NOAH025_M_V2.0/ }\end{array}$ \\
\hline
\end{tabular}

GLDAS version-2. Then, on the basis of validated data, trends of climate data over India were analyzed, and their relationship with the trends and variability of $E T$ were derived. Coefficient of correlation $(r)$ and RMSE were employed to examine agreement between the datasets. Monthly, seasonal (DJF, MAM, JJA and SON) and annual ET over India from 1983 to 2006 were computed, and then used to study seasonal and inter-annual dynamics of $E T$ and its relation with climatic variations.

\subsection{Mann-Kendal test}

Non-parametric Mann-Kendall (MK) test (Jain and Kumar 2012; Das et al. 2014) was used in this analysis to determine presence and extent of trends in seasonal and inter-annual ET and climatic parameters over India for the period 19832006. In MK test, the null hypothesis $\left(H_{0}\right)$ assumes that there has been no trend (the data is independent and randomly ordered) in the data over a period and this is tested against the alternate hypothesis $\left(H_{1}\right)$, which assumes that there has been a trend (increasing or decreasing) over the period. The mathematical equations for calculating Mann-Kendell statistics $S$, and standardized test statistics $Z$ are as follows:

$$
S=\sum_{i=1}^{n-1} \sum_{j=i+1}^{n} \operatorname{sign}(T j-T i)
$$

where $n$ the is length of the dataset, $T j$ and $T i$ are the time series data in chronological order in years' values $j$ and $i, j>i$, respectively. The function sign $(T j-T i)$ assumes the following values:

$$
\operatorname{sign}(T j-T i)=\left\{\begin{array}{ll}
1 & \text { if } T j-T i>0 \\
0 & \text { if } T j-T i=0 \\
-1 & \text { if } T j-T i<0
\end{array}\right\}
$$

Under the hypothesis of independent and randomly distributed random variables, when $n \geq 8$, the $S$ statistic is approximately normally distributed with zero mean and the variance $\left(\sigma^{2}\right)$ for the $S$-statistic is calculated as follows:

$$
\sigma^{2}=\frac{n(n-1)(2 n+5)-\sum t_{i}(i)(i-1)(2 i+5)}{18}
$$

where $t_{i}$ represents the number of ties to extent $i, n$ is the length of the time series. The summation term in the numerator was used only if the data series includes tied values. The standard test statistic $Z$ is calculated as follows: 


$$
Z=\left\{\begin{array}{cl}
\frac{s-1}{\sigma} & \text { for } S>0 \\
0 & \text { for } S=0 \\
\frac{s+1}{\sigma} & \text { for } S<0
\end{array}\right\} .
$$

The test statistic $Z$ is used to measure the presence of statistically significant trends in time series data. This statistic is employed to test null hypothesis, $H_{0}$. A positive $Z$ shows an increasing trend in the times series, whereas a negative $Z$ shows a decreasing trend. In this analysis, if $Z>+1.96$ or $Z<-1.96$, the null hypothesis $\left(H_{0}\right)$ is rejected at the $95 \%$ significance level. The estimate for the magnitude of the slope of trend $b$ was determined using Sen's estimator (Sen 1968), which is the median of slopes of all data value pairs.

$$
b=\operatorname{median}\left[\frac{(T j-T i)}{j-i}\right], \text { for all } i<j
$$

where $b$ is the slope between data point $T_{j}$ and $T i$ measured at times $j$ and $i$, respectively. $R$ package (rkt) was used to perform MK test in this analysis. To know the biome level contribution of $E T$ over India, annual ET values for the pixels were extracted using land use/land cover map (1985, 1995 and 2005) and calculated biome level mean climatic ET to know their annual ET potential. To understand the magnitude of the relation between ET and various climatic variables (precipitation, temperature, soil moisture and solar radiation), grid level Pearson correlation was performed using 'corLocal' function in $R$.

\section{Results and discussions}

\subsection{Validation of satellite ET product}

Biome specific ET generated using NOAA time series NDVI data was validated using daily lysimeter ET records at 48 stations located in croplands across India. Good agreement was observed between both the datasets. Comparison between satellite ET and lysimeter ET for some of the sites are depicted in figure 2 . It can be seen that the satellite ET was consistent with a characteristic temporal pattern of ET obtained from lysimeter. Seasonal (DJF, MAM, JJA, and SON) and annual ET comparison between both the datasets are presented in table 2. Good correlation between both the datasets was observed in winter
(DJF) and summer (MAM), whereas relatively poor correlation was observed in monsoon (JJA) and post-monsoon (SON) periods. The degree of agreement between both the dataset was close to 1 in all the cases except JJA. Coefficient of determination $\left(R^{2}\right)$ ranged from 0.52 (JJA) to 0.78 (DJF), summer season had an RMSE, which was $38 \%$ of mean lysimeter $E T$ and found to have the highest error.

Overall, the comparison analysis showed that the NOAA NDVI derived ET was reliable for carrying out studies over the Indian subcontinent. Across all sites, satellite ET tends to underestimate lysimeter data with larger bias in JJA and SON. This difference is likely due to scaling issues and prominent atmospheric effects in monsoon season which influences optical remote sensing data. Satellite ET $(8 \mathrm{~km} \times 8 \mathrm{~km})$ pixels do not match with lysimeter point observation data and represent $E T$ values at larger scales as compared to ground measured ET values. Discrepancies between both the datasets in JJA and SON could be due to use of coarse spatial resolution surface meteorology data to derive $E T$ from $8 \mathrm{~km} \times 8 \mathrm{~km}$ spatial resolution satellite data.

\subsection{Validation of climate data}

Soil moisture and shortwave radiation product obtained from $\mathrm{CPC}$ and $\mathrm{SRB}$ to determine the influence of climate parameters on ET was validated using soil moisture and shortwave radiation products acquired from GLDAS version-2. These results are based on our assumptions that GLDAS version-2 products most accurately characterized the respective parameters over India for the study period. Scatter plot between both the climate datasets are depicted in figure 3 with correlation coefficient, slope and RMSE. Good correlation between both the datasets was observed with correlation coefficients ranging from 0.78 (soil moisture) to 0.92 (solar radiation). Soil moisture obtained from CPC indicated a slight overestimation when compared to the reference soil moisture data acquired from GLDAS with RMSE of 63.7 $\mathrm{mm}$, which was $25 \%$ of GLDAS mean soil moisture. SRB radiation data was highly consistent with the GLDAS radiation data with RMSE $11.4 \mathrm{~W} \mathrm{~m}^{-2}$, which was just $5.7 \%$ of GLDAS mean incoming shortwave radiation flux. This high correlation could be due to the use of some of the common satellite, gauge and station sources to derive 

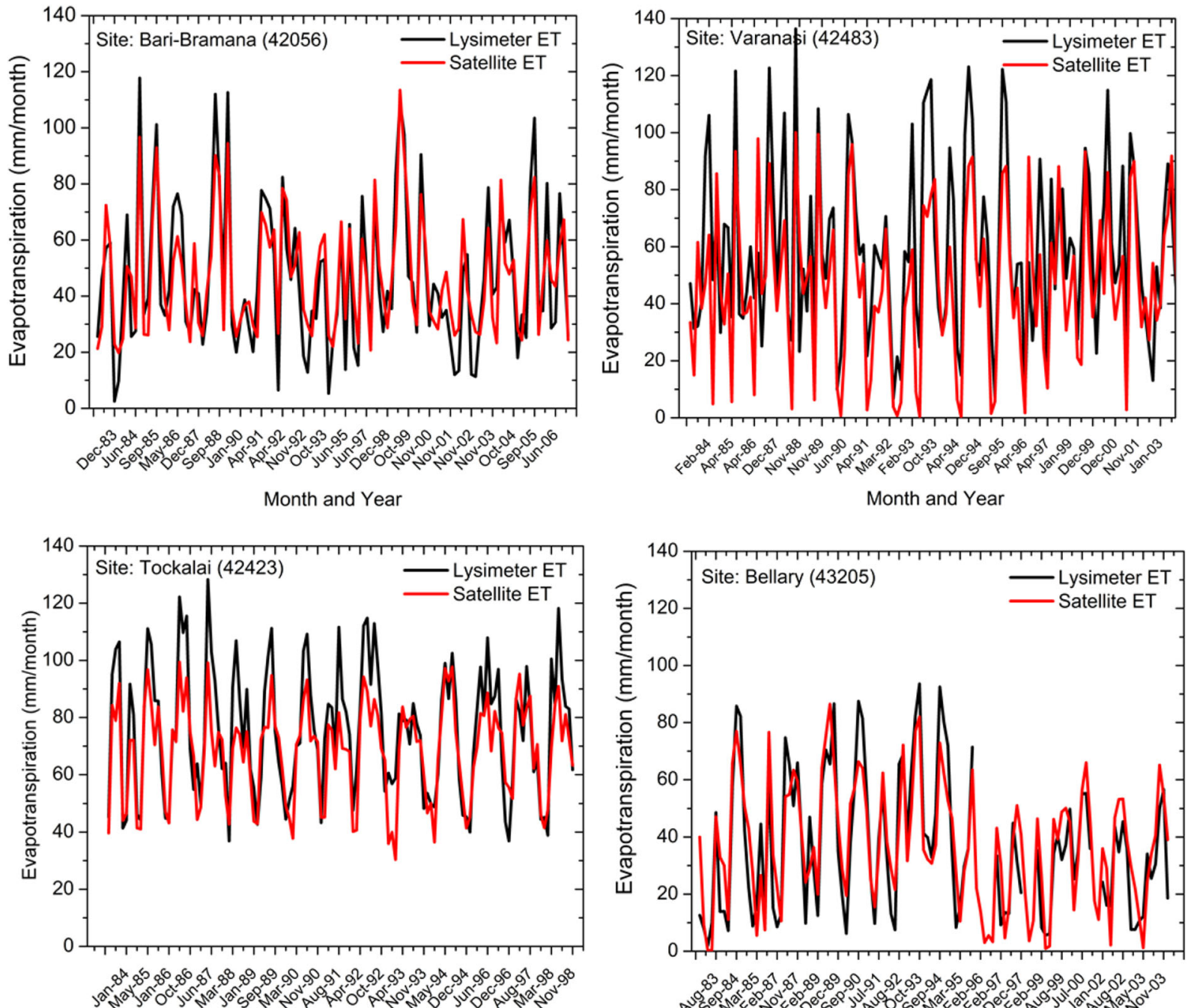

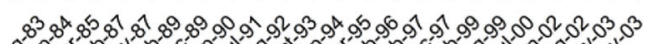

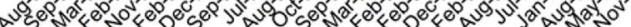

Month and Year
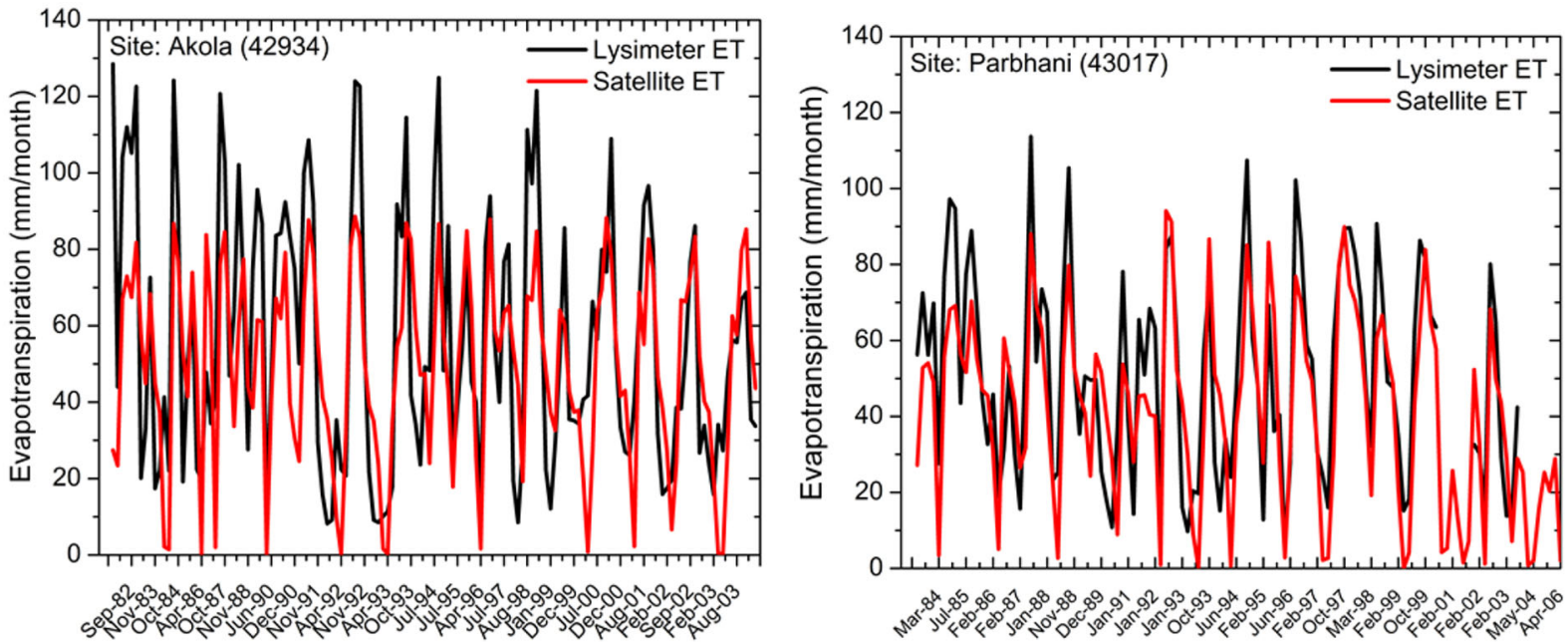

Figure 2. Comparison of satellite-derived evapotranspiration with $E T$ measured by lysimeter over different locations India between 1983 and 2006.

these products. The precision of climate data for determining regional climate variability is within the range of $5 \%-25 \%$.

\subsection{Seasonal variations of ET}

Spatial distribution of mean seasonal ET for four seasons corresponding to winter northeast 
Table 2. Agreement statistics between lysimeter ET and satellite derived ET at different temporal scales over India.

\begin{tabular}{|c|c|c|c|c|c|}
\hline Season & $\begin{array}{l}\text { Mean Lysimeter } \\
\text { ET }(\mathrm{mm})\end{array}$ & $\begin{array}{l}\text { Mean satellite ET } \\
(\mathrm{mm})\end{array}$ & $R^{2}$ & $\begin{array}{l}\text { Degree of } \\
\text { agreement (d) }\end{array}$ & $\begin{array}{c}\text { RMSE } \\
(\%)\end{array}$ \\
\hline Monthly & 50.06 & 47.30 & 0.72 & 0.93 & 27.93 \\
\hline DJF & 113.44 & 111.85 & 0.78 & 0.93 & 18.88 \\
\hline MAM & 129.05 & 104.32 & 0.74 & 0.90 & 37.92 \\
\hline JJA & 200.64 & 160.67 & 0.52 & 0.87 & 30.40 \\
\hline $\mathrm{SON}$ & 222.42 & 199.24 & 0.61 & 0.96 & 19.24 \\
\hline Annual & 655.73 & 587.88 & 0.75 & 0.99 & 17.69 \\
\hline
\end{tabular}
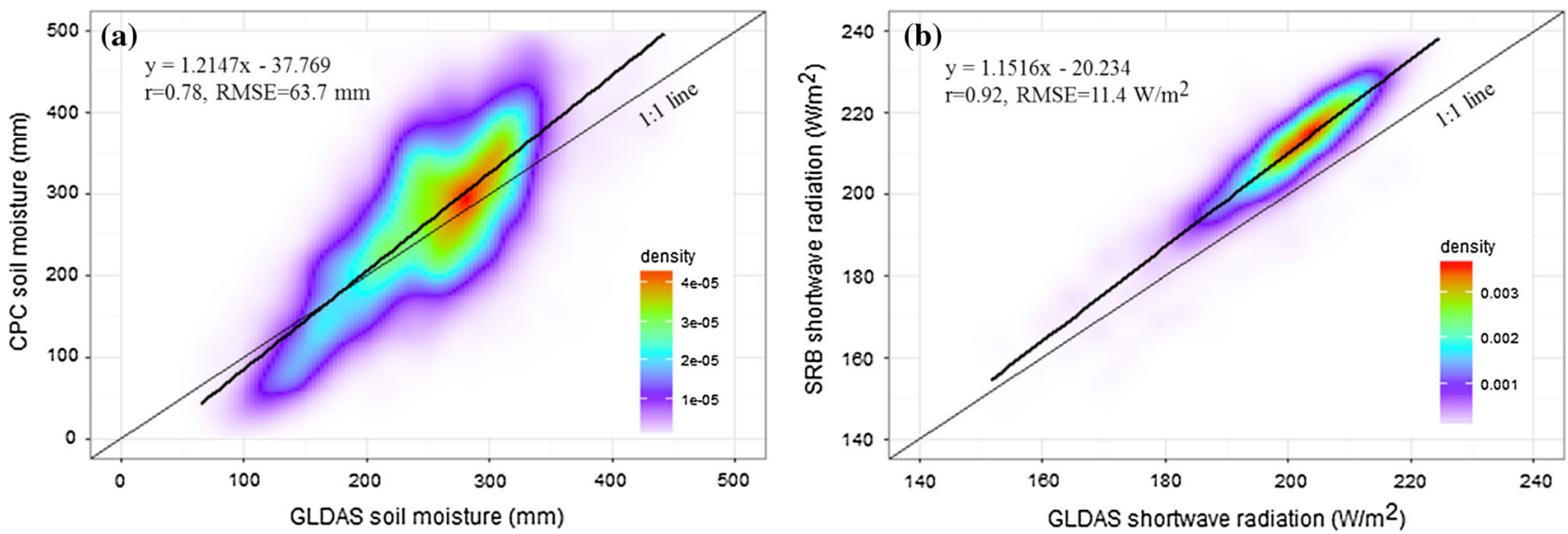

Figure 3. Scatter plots between soil moisture and incoming shortwave radiation data used in this study to determine influence on inter-annual variability of ET over India for the period 1983-2006, (a) soil moisture (CPC) vs. soil moisture (GLDAS) and (b) incoming shortwave radiation (SRB) vs. incoming shortwave radiation (GLDAS). The solid black thin line represents 1:1 best-fit line, correlation coefficient $(r)$, and RMSE are given in each plot.

monsoon (December-February), spring or pre-monsoon (March-May), southwest summer monsoon (June-August) and autumn or post monsoon (September-November) for the study period (1983-2006) is shown in figure 4. The normalized cumulative histogram plot of seasonal mean $E T$ for the study period is depicted in figure 5 . Distinct spatial patterns can be seen over India during different seasons. During DJF, ET varied considerably $\left(0-400 \mathrm{~mm}\right.$ season $\left.^{-1}\right)$ with an average of $108.57 \mathrm{~mm}$ season $^{-1}$. More than $35 \%$ pixels in the country indicated $E T<100 \mathrm{~mm}^{\text {season }}{ }^{-1}$ in this season. Low magnitude in the season was mainly due to leaf fall in deciduous forests, relatively less agricultural crop growth and dry weather with little or no rain during northeast winter monsoon. Relatively high ET (100-160 mm season $\left.{ }^{-1}\right)$ compared to other agricultural lands in the country was observed over the Indo-Gangetic plains and Tamil Nadu. It was mainly due to peak growth stages of winter crops. Lowest annual ET levels were observed in the country during spring or pre-monsoon season with a mean ET of
$66.9 \mathrm{~mm} \mathrm{season}^{-1}$. More than $75 \%$ pixels in the country exhibited $E T<100 \mathrm{~mm}^{\text {season }}{ }^{-1}$. Senescence of agriculture crops and deciduous forests, extreme high temperature, low relative humidity and very low or no availability of soil moisture were the reasons for the low ET levels during the season.

Compared to DJF and MAM, high range of ET was observed during southwest summer monsoon period. Cumulative frequency plot shifted towards higher side of ET values. More than $75 \%$ pixels in the country showed ET more than $100 \mathrm{~mm}$ season $^{-1}$. The mean ET during JJA was $135.90 \mathrm{~mm} \mathrm{season}^{-1}$. The highest magnitude of $E T$ during JJA was associated with maximum growth of agriculture crops (Indo-Gangetic plain and eastern peninsula) and forests, adequate soil moisture and optimal weather for high ET. During autumn or the post monsoon season, the magnitude of the ET further increased and achieved its peak value all over the country. The cumulative frequency plot indicated that, more than $85 \%$ pixels in the country showed ET more than $100 \mathrm{~mm}^{\text {season }}{ }^{-1}$ with mean of $164.36 \mathrm{~mm}^{\text {season }}{ }^{-1}$. This high ET 

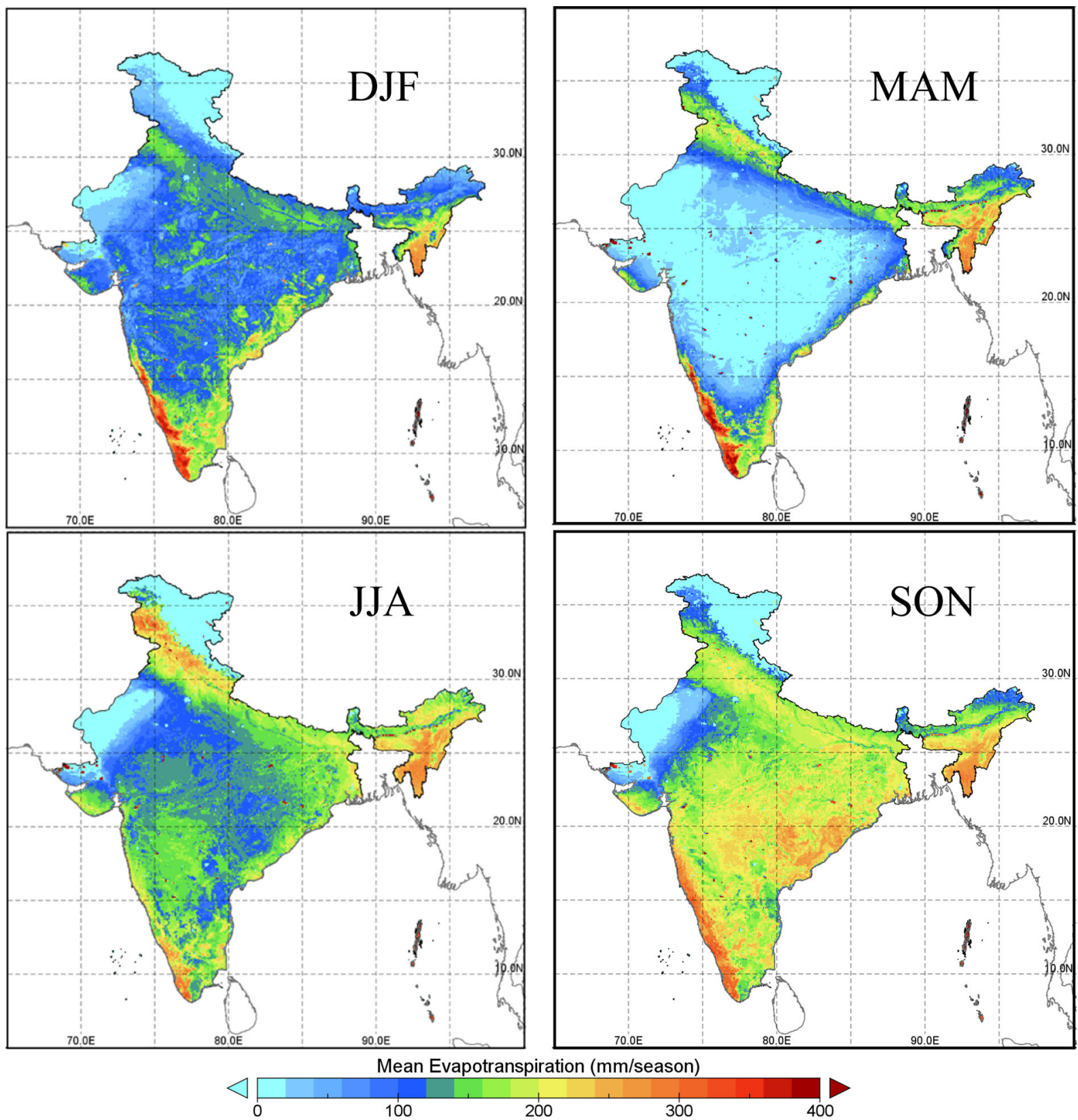

Figure 4. Climatological mean seasonal land evapotranspiration for different seasons over India.

coincided with peak growth of most of deciduous vegetation, sufficient soil moisture and very conducive weather conditions.

Inter-seasonal trends and variability of ET over India for four seasons (DJF, MAM, JJA and SON) over 24 years (1983-2006) is shown in figure 6. An increasing trend in $E T$ is seen during northeast winter monsoon $\left(m=0.156 \mathrm{~mm}\right.$ season $^{-1}$ year $\left.^{-1}\right)$ and spring or pre-monsoon $(m=0.068 \mathrm{~mm}$ season $^{-1}$ year $^{-1}$ ) season. In contrast, a significant $(p<0.1)$ decreasing trend in ET was observed during southwest summer monsoon period $\left(m=-0.320 \mathrm{~mm}\right.$ season $^{-1}$ year $\left.^{-1}\right)$ and autumn or post-monsoon $\left(m=-0.188 \mathrm{~mm} \mathrm{season}^{-1}\right.$ year $\left.^{-1}\right)$ season. The increasing trend in ET during northeast winter monsoon and spring or pre-monsoon was mainly due to increase in irrigation and cropping intensity as well as improvements in crop management practices in arid and semiarid regions of India (Milesi et al. 2010). The decreasing trend in southwest summer monsoon and the post-monsoon seasons might be due to solar dimming over major parts of India owing to rise in aerosol load and cloudiness (Padma Kumari and 


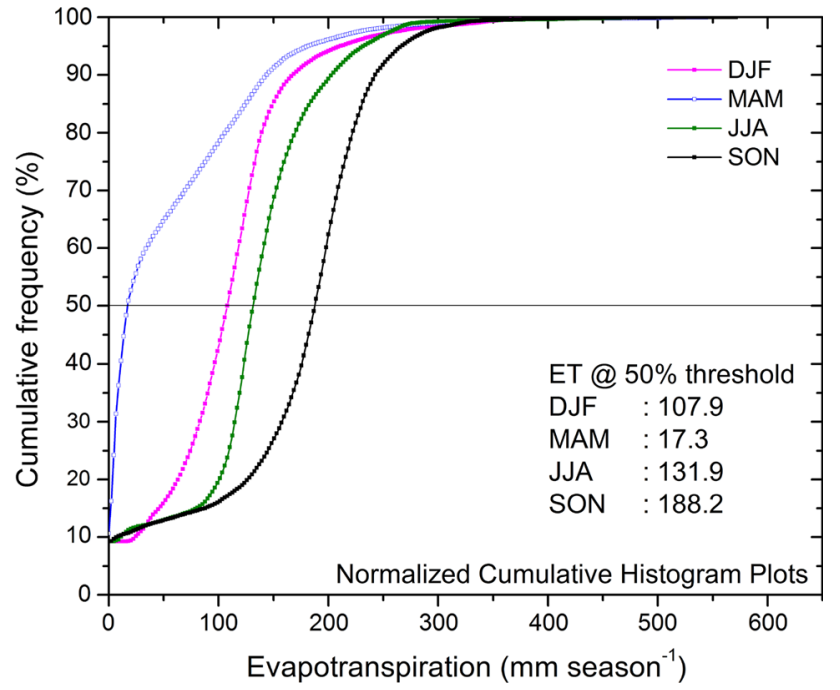

Figure 5. Normalized cumulative histogram plot of seasonal mean evapotranspiration for the study period.

Goswami 2010; Soni et al. 2012; Singh and Kumar 2016).

\subsection{Annual variability of ET}

Spatial pattern of multiyear (1983-2006) mean annual $E T$, standard deviation, coefficient of variation $(C V \%), E T$ trend, and pixels having $p$ values at $<0.05$ and $<0.1$ are depicted in figure $7(\mathrm{a}-\mathrm{f})$ and inter-annual variability over Indian subcontinent are depicted in figure $7(\mathrm{a}-\mathrm{d})$. The figures clearly indicate strong regional variations corresponding to native vegetation types and climatic conditions. Annual ET averaged for the study period varied from 0 to $>1000 \mathrm{~mm}_{\text {year }}{ }^{-1}$. Arid regions with desert, barren/sparsely vegetated lands in western India (parts of Rajasthan and Gujarat) showed the lowest ET, ranging from 0 to $200 \mathrm{~mm}_{\text {year }}{ }^{-1}$, while the highest ET (800 for >1000 $\mathrm{mm} \mathrm{year}^{-1}$ ) was observed in the Western Ghats (parts of Kerala and Karnataka) and forested regions in Mizoram, Manipur, Tripura and Nagaland states of northeastern India.

Mean annual ET for different land cover types for three decades are presented in table 3 and average of three decades is depicted in figure 8 . Mangrove forest indicated the highest mean annual ET (980.18 $\mathrm{mm} \mathrm{year}^{-1}$ ) among all the land use land cover types followed by plantations with $844.73 \mathrm{~mm}_{\text {year }}{ }^{-1}$. The lowest $E T$ was observed in scrublands with $488.51 \mathrm{~mm}$ year ${ }^{-1}$ preceded by $493.72 \mathrm{~mm} \mathrm{year}^{-1}$ in evergreen needle leaf forest. Wide range in standard deviation $(S D)$ of annual ET (figure $7 \mathrm{~b}$ ) was observed for the entire study period. The SD showed maximum deviation (20 to $>80 \mathrm{~mm} \mathrm{year}^{-1}$ ) for regions where mean annual ET was higher, while minimum $S D\left(0\right.$ to $\left.<20 \mathrm{~mm}_{\text {year }}{ }^{-1}\right)$ was observed in regions where mean annual ET was lower.

Annual coefficient of variation (figure 7c) over the study region ranged from 0 to $20 \%$. Low standard deviation with high mean annual ET in forested regions showed low $C V(<5 \%)$, whereas
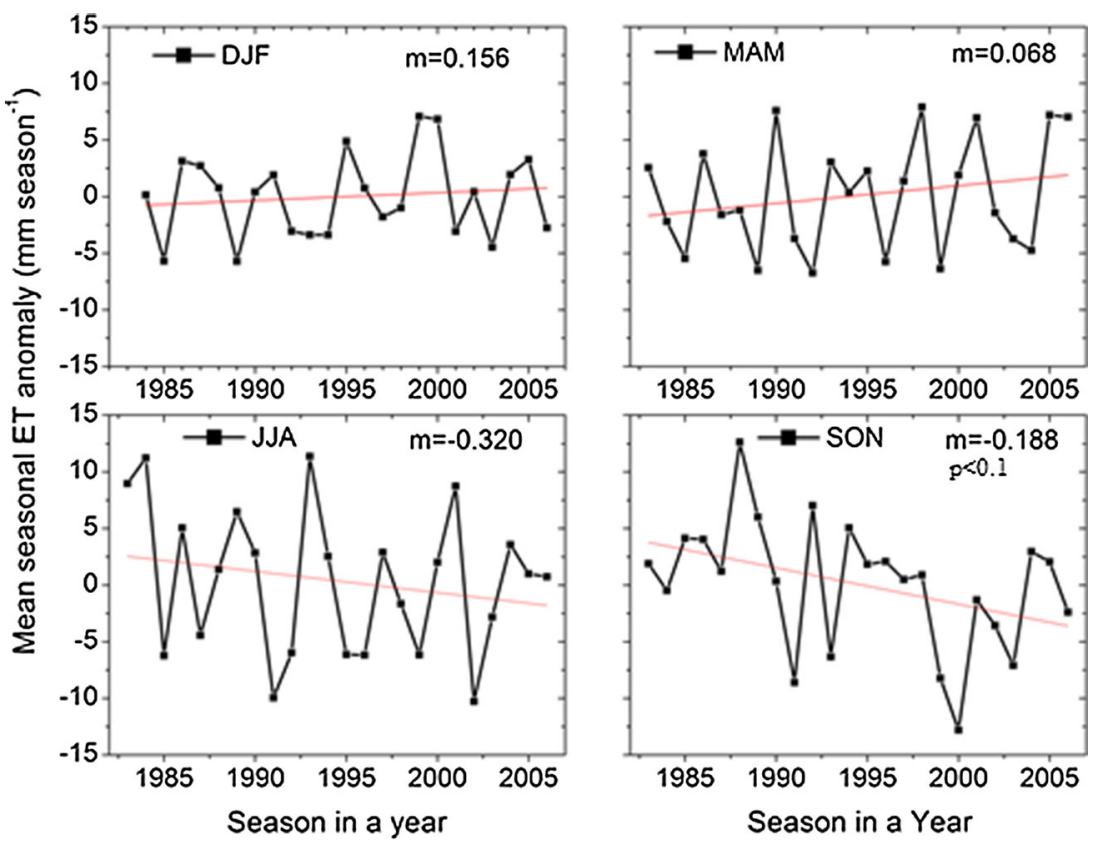

Figure 6. Seasonal trends of mean evapotranspiration in India. $m$ (units: $\mathrm{mm} / \mathrm{season}$ ) represents slope of the trend line. 

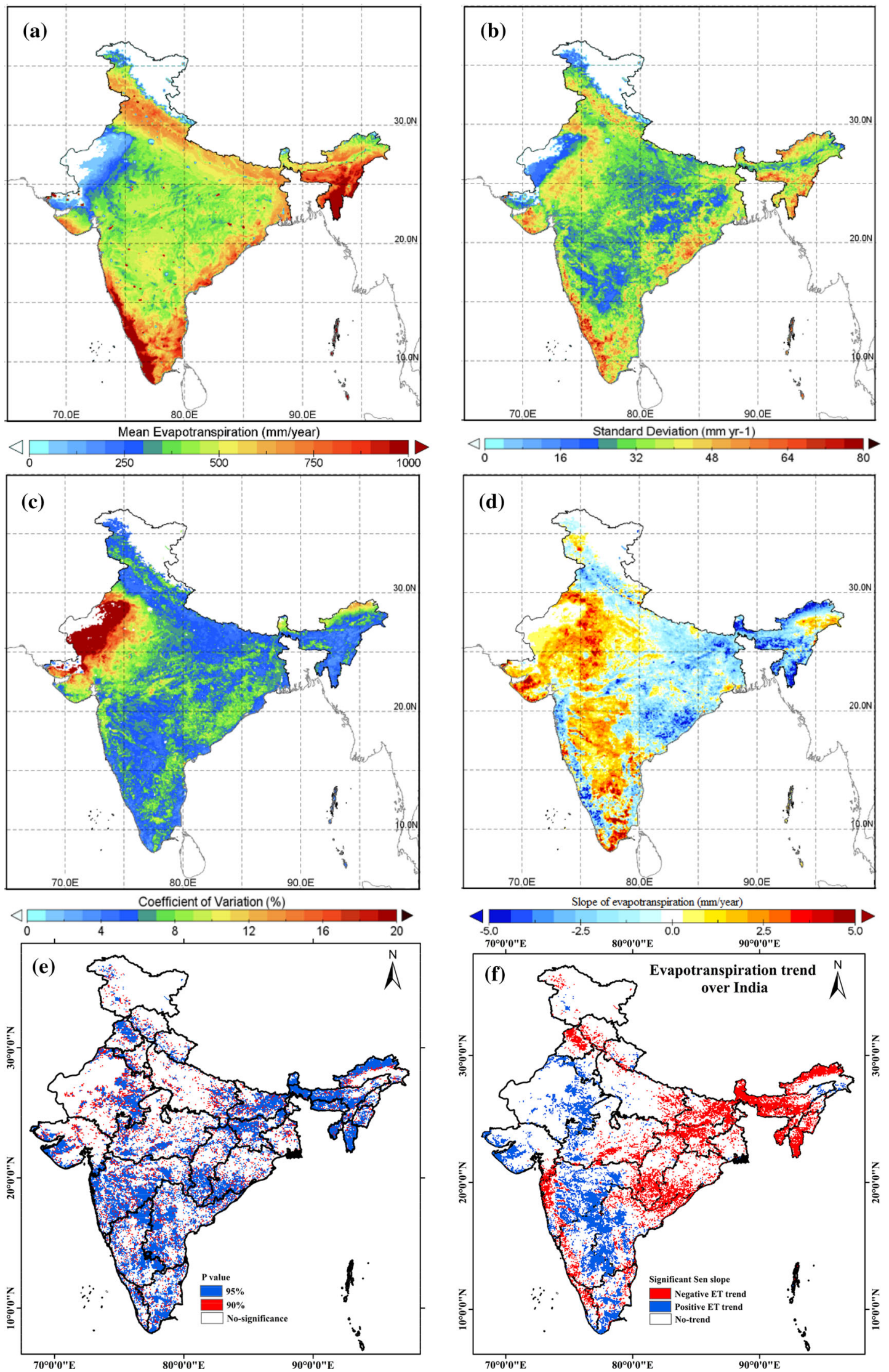

Figure 7. Climatological (a) mean annual ET, (b) standard deviation, (c) coefficient of variation (\%), and (d) ET trend, (e) pixels having $p$ values $<0.05$ and $<0.1$, and (f) pixels having significant positive and negative trend in $E T$ over India. 
Table 3. Decadal variability of evapotranspiration across various land use land cover in India.

\begin{tabular}{|c|c|c|c|c|c|c|c|c|c|c|}
\hline \multirow[b]{2}{*}{ Code } & \multirow[b]{2}{*}{ Land use land cover } & \multicolumn{3}{|c|}{ 1983-1989 } & \multicolumn{3}{|c|}{ 1990-1999 } & \multicolumn{3}{|c|}{ 2000-2006 } \\
\hline & & Mean & $\mathrm{SD}$ & $\mathrm{CV}(\%)$ & Mean & $\mathrm{SD}$ & $\mathrm{CV}(\%)$ & Mean & $\mathrm{SD}$ & $\mathrm{CV}(\%)$ \\
\hline 1 & Deciduous broadleaf forest & 508.16 & 174.91 & 34.42 & 486.71 & 169.86 & 34.90 & 523.22 & 213.97 & 40.90 \\
\hline 2 & Cropland & 509.98 & 156.43 & 30.67 & 510.72 & 143.45 & 28.09 & 514.57 & 139.41 & 27.09 \\
\hline 4 & Mixed forest & 672.69 & 264.21 & 39.28 & 653.20 & 255.33 & 39.09 & 647.54 & 245.94 & 37.98 \\
\hline 5 & Shrubland & 491.78 & 211.01 & 42.91 & 485.83 & 196.86 & 40.52 & 487.93 & 193.66 & 39.69 \\
\hline 10 & Plantations & 853.75 & 308.23 & 36.10 & 844.75 & 305.25 & 36.13 & 835.68 & 307.51 & 36.80 \\
\hline 12 & Mangrove forest & 984.55 & 562.97 & 57.18 & 968.06 & 566.37 & 58.51 & 987.93 & 592.16 & 59.94 \\
\hline 14 & Grassland & 555.50 & 200.18 & 36.04 & 553.20 & 198.66 & 35.91 & 538.82 & 197.53 & 36.66 \\
\hline 15 & Evergreen broadleaf forest & 714.03 & 276.19 & 38.68 & 702.86 & 272.89 & 38.82 & 690.65 & 275.06 & 39.83 \\
\hline 16 & Deciduous needleleaf forest & 520.54 & 92.28 & 17.73 & 477.09 & 82.89 & 17.37 & 483.53 & 87.66 & 18.13 \\
\hline 19 & Evergreen needleleaf forest & 624.20 & 105.66 & 16.93 & 624.74 & 101.73 & 16.28 & 616.62 & 95.69 & 15.52 \\
\hline
\end{tabular}

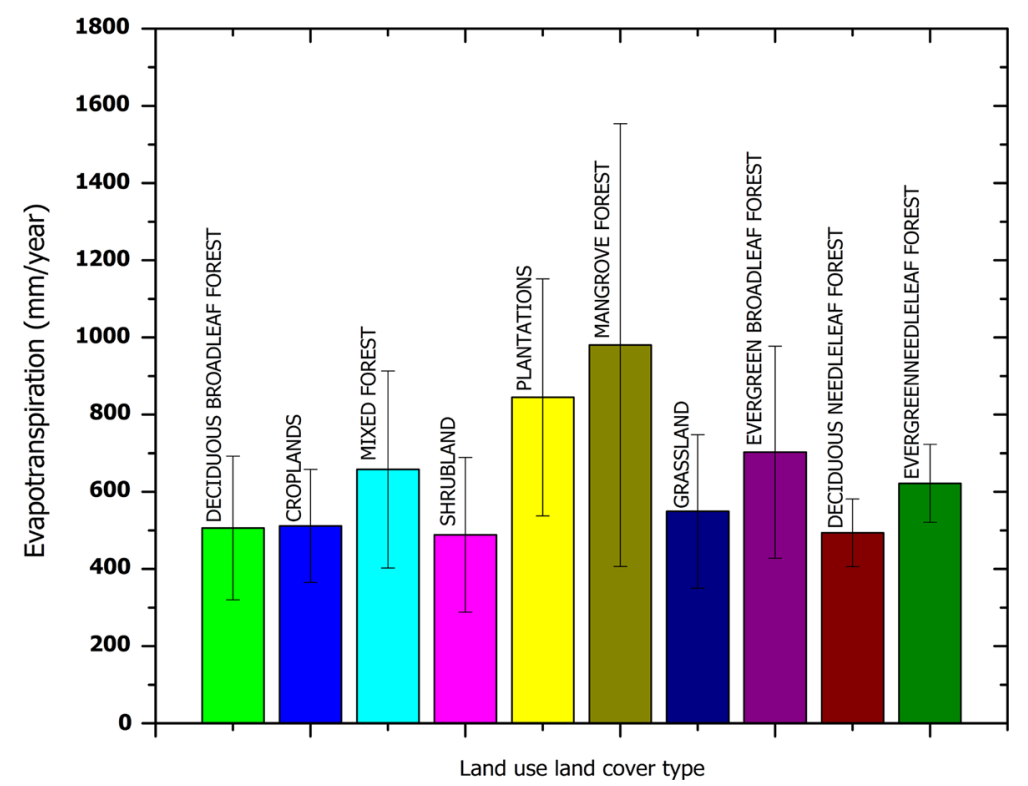

Figure 8. Mean annual evapotranspiration over different vegetation types in India.

high SD associated with low mean annual ET indicated high $C V(>15 \%)$, i.e., in barren/sparsely vegetated regions of western India. The presence of trend in ET determined using the Mann-Kendall test including distributed Sen's Slope estimates for the entire Indian subcontinents depicted in figure $7(\mathrm{~d})$ and pixels having $p$ values (derived from Mann-Kendal test) $<0.05$ and 0.1 (i.e., $95 \%$ and $90 \%$ confidence level) are shown in figure $7(\mathrm{e})$. Increasing or decreasing trend in $E T$ at $p<0.05$ and $p<0.1$ is shown in figure $7(\mathrm{f})$. ET indicated an increasing ( 0 to $>5 \mathrm{~mm} \mathrm{year}^{-1}$ ) trend (figure $7 d$ ) for the study period in dry regions (parts of Rajasthan, Gujarat, western Madhya Pradesh) and in semi-arid regions (parts of Maharashtra, Karnataka, Tamil Nadu and Andhra Pradesh), whereas significant decreasing trend of ET $(<-5$ to $0 \mathrm{~mm}$ year $^{-1}$ ) was observed in northeastern forest regions, parts of Western Ghats, Orissa and Chhattisgarh.

Mean annual ET for forested regions was plotted against study years and the slope was calculated using MK test (figure 9). Significant decreasing trend $\left(m=-1.75 \mathrm{~mm}\right.$ year $^{-1}, F=17.41$, $P<0.01)$ in $E T$ was observed over forests, whereas small increasing trend was observed in non-forested regions with $m=0.0817 \mathrm{~mm}_{\text {year }}{ }^{-1}$. Overall, a net decreasing trend was found over India with a slope of $-2.2 \mathrm{~mm}$ decade ${ }^{-1}$.

This decreasing trend was mainly due to significant reduction in mean annual ET over forested regions of south-western Ghats and north-eastern 


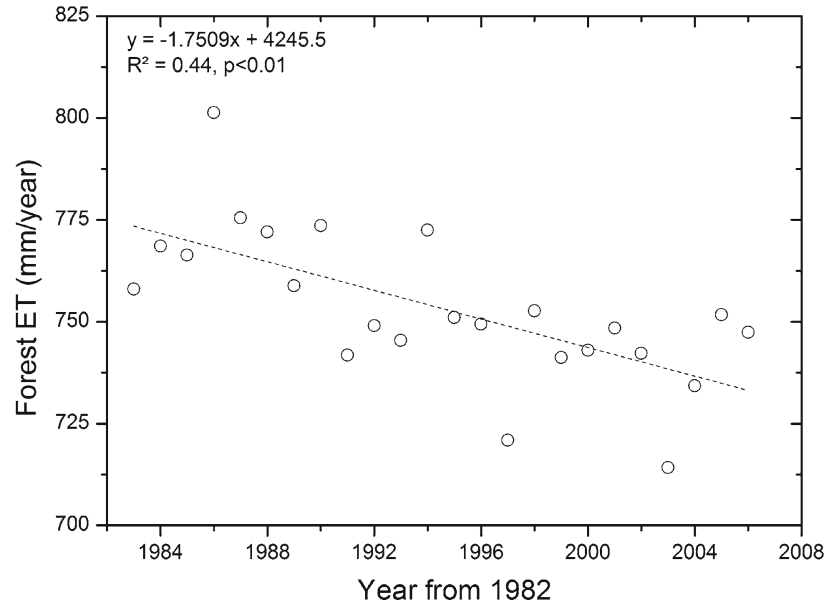

Figure 9. Trend in forest ET over India from 1983 to 2006.

states. This might be due to dimming in solar radiation (Padma Kumari et al. 2007; Padma Kumari and Goswami 2010; Singh and Kumar 2016) and decrease in rainfall during the study period over the regions (see section 4.3). This may also be due to shifting cultivation, which is still practiced in some north-eastern states leading to significant change in land cover (State of Forest Report 1999). In contrast, considerable increase in area under irrigation and a change in cropping pattern and cultivars might have increased annual ET over non-forest regions (figure 7d) particularly over arid and semi-arid regions of western and southern parts of India (Gholkar et al. 2014). But these contrasting situations need investigation at finer scales with more statistics on crops, irrigation and intensification of agriculture.

\subsection{Trends in climatic parameters}

Trends in climatic parameters for the study period are shown in figure 10. Spatial variation of Sen's slope estimate for precipitation, temperature, soil moisture and insolation is depicted in the left panel in figure 10 and pixels having $p$ values $<0.05$ and 0.1 (i.e., $95 \%$ and $90 \%$ confidence level) are shown in the right panel in figure 10. The mean temperature increased over most parts of the country except for certain pockets. Significant $(p<0.05)$ increasing trend $\left(0.01\right.$ to $0.04^{\circ} \mathrm{C} /$ year $)$ in temperature was observed in parts of north India (Jammu and Kashmir, Punjab, etc.), western India (Rajasthan, Gujarat), eastern states (Assam, Mizoram, etc.), central India (Madhya Pradesh) and in parts of Maharashtra state.
Precipitation indicated significant increasing trend in the Gujarat region $\left(>10 \mathrm{~mm}_{\text {year }}{ }^{-1}\right)$, whereas a significant decreasing trend $(<-6.5 \mathrm{~mm}$ year $\left.{ }^{-1}\right)$ was observed in Indo-Gangetic plain and the north eastern states. With increasing precipitation, soil moisture increased significantly $\left(>2 \mathrm{~mm} \mathrm{year}^{-1}\right)$ in semi-arid and arid regions of Gujarat, Rajasthan and most parts of the Deccan plateau. Parts of Uttar Pradesh and northeastern states showed significant negative trend $\left(>-2 \mathrm{~mm} \mathrm{year}^{-1}\right)$ in soil moisture. Increasing trend in ET can be clearly seen in the same regions in figure $7(\mathrm{~d})$, indicating a direct influence of soil moisture on ET variability. Significant increasing trend in incident solar radiation (figure $10 \mathrm{~g}-\mathrm{h}$ ) was observed in parts of Jammu Kashmir, Tamil Nadu, Maharashtra and Karnataka with $>0.3 \mathrm{~W} \mathrm{~m}^{-2}$ year $^{-1}$, while significant negative trend $\left(>0.9 \mathrm{~W} \mathrm{~m}^{-2}\right.$ year $\left.^{-1}\right)$ in insolation was observed in parts of Uttar Pradesh, Bihar and north eastern states, which can be attributed to increased cloud cover and aerosol concentrations over the region. Decrease in insolation in the Western Ghats can be attributed to increased cloud cover, which is evident from the increasing precipitation in that region (figure 10a-b).

\subsection{Correlation of ET with climatic parameters}

The grid level correlation between annual evapotranspiration and meteorological parameters (precipitation, mean temperature, soil moisture and solar radiation) over India was derived (figure 11) to understand the influence of regional climatic parameters on inter-annual ET dynamics over India during the study period.

ET indicated a strong positive correlation $(r>$ $0.5)$ with precipitation (figure 11a) and soil moisture (figure 11c) in arid (Rajasthan, Gujarat) and semi-arid regions (Maharashtra and Karnataka), whereas significant negative correlation was observed in parts of south-western Ghats and north-eastern regions. A significant negative correlation $(r<-0.5)$ of $E T$ with mean temperature (figure 11b) and insolation (figure 11d) was observed over dry regions (Rajasthan and parts of Gujarat) and semi-arid regions, whereas positive correlation $(r>0.5)$ was observed in forest regions in the Brahmaputra basin of Arunachal Pradesh. 

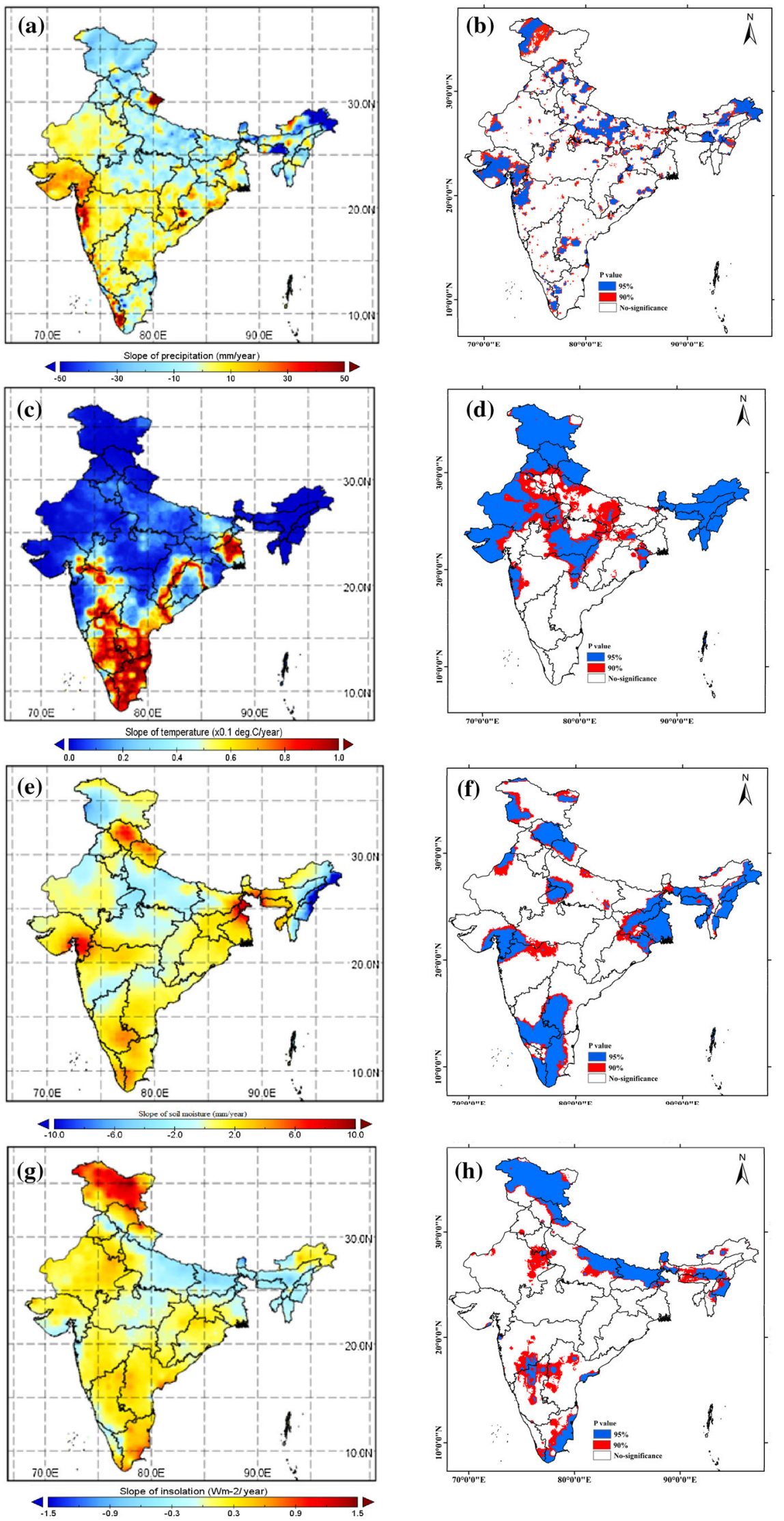

Figure 10. Spatial trend and pixels having $p$ values $<0.05$ and $<0.1$ (i.e., $95 \%$ and $90 \%$ confidence level) of precipitation $(\mathbf{a}-\mathbf{b})$, mean temperature $(\mathbf{c}-\mathbf{d})$, soil moisture $(\mathbf{e}-\mathbf{f})$, and solar radiation $(\mathbf{g}-\mathbf{h})$ over India for the period $1983-2006$. 

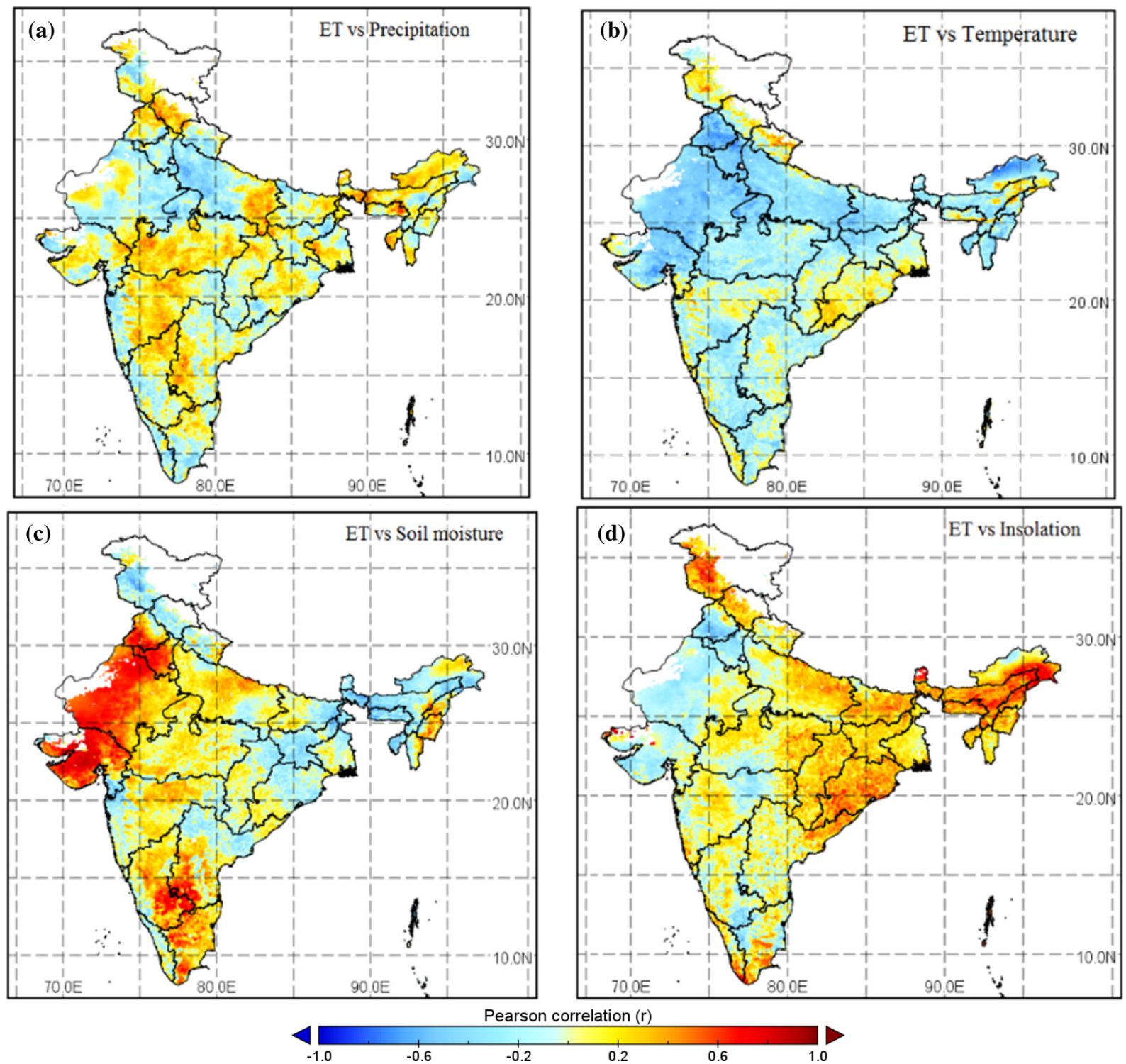

Figure 11. Correlation of ET with (a) precipitation, (b) mean temperature, (c) soil moisture and (d) solar radiation over India.

\section{Conclusion}

Long-term NOAA AVHRR derived terrestrial evapotranspiration data was used to investigate its trend and variability over India for the period 1983-2006. Trend analysis using the non-parametric Mann-Kendall test indicated that the domain average ET declined during the period at a rate of $0.22 \mathrm{~mm}$ year $^{-1}$. A significant decreasing trend $\left(m=-1.75 \mathrm{~mm} \mathrm{year}^{-1}, F=17.41, P<0.01\right)$ was observed in forest regions. Seasonal analysis showed a decreasing trend during southwest summer monsoon and post-monsoon period, whereas increasing trend during northeast winter monsoon and pre-monsoon periods. Despite an overall net decline in the country, a considerable increase in
ET was observed over croplands of central and western parts of the country. Grid level correlation with various climatic parameters exhibited a strong positive correlation of ET with soil moisture and precipitation over semi-arid and arid regions, whereas a negative correlation found with temperature and insolation in dry regions of western India. Overall, agronomic improvements were the principal drivers of ET enhancement. Solar dimming resulted from deteriorated aerosol and air pollution could be one of the major reasons for net decline of ET. Continuation of declining trends will likely cause a reduction in terrestrial primary productivity and an energy partitioning preference towards sensible heat, rather than latent heat, which accelerated surface heating, and intensified 
land-atmosphere interactions. Future studies on the effects of ET changes on the hydrological cycle, carbon cycle, and energy partitioning are needed to account for the feedbacks to the climate.

\section{Acknowledgements}

This research was carried out under ISRO-GBP EMEVS Project. Authors are thankful to Director, Space Applications Centre, ISRO Ahmedabad. SKG wishes to acknowledge the fellowship granted by SAC to carry out the research. The authors are grateful to NTSG, University of Montana for providing evapotranspiration data. We would like to thank IMD, CPC and GES DISC for providing climate datasets. We sincerely thank Oak Ridge National Laboratory (ORNL) Distributed Active Archive Center (DAAC) for providing Decadal Land Use and Land Cover Classifications across India. We are also thankful to Goddard-Institute-Space-Studies for providing panoply software. We express our gratitude to the editor and anonymous reviewers for their constructive comments, which improved the manuscript substantially.

\section{References}

Asoka A and Mishra V 2015 Prediction of vegetation anomalies to improve food security and water management in India; Geophys. Res. Lett. 42(13) 5290-5298.

Bala G, Joshi J, Chaturvedi R K, Gangamani H V, Hashimoto H and Nemani R 2013 Trends and variability of AVHRR-derived NPP in India; Remote Sens. 5 810829.

Bates B, Kundzewicz Z W, Wu S and Palutikof J 2008 Climate change and water: Technical Paper vi; Intergovernmental Panel on Climate Change (IPCC).

Bhattacharya B K, Mallick K, Patel N K and Parihar J S 2010 Regional clear sky evapotranspiration over agricultural land using remote sensing data from Indian geostationary meteorological satellite; J. Hydrol. $\mathbf{3 8 7}$ 65-80.

Biggs T W, Scott C A, Rajagopalan B and Turral H N 2007 Trends in solar radiation due to clouds and aerosols, southern India, 1952-1997; Int. J. Climatol. 27 15051518.

Bouchet R J 1963 Evapotranspiration reelle, evapotranspiration potentielle, et production agricole; Ann. Agron. 14 $743-824$.

Burt T P and Shahgedanova M 1998 A historical record of evaporation losses since 1815 calculated using long-term observations from the Radcliffe Meteorological Station, Oxford, England; J. Hydrol. 205 101-111.
Chanda K, Maity R, Sharma A and Mehrotra R 2014 Spatiotemporal variation of long-term drought propensity through reliability-resilience-vulnerability based drought management index; Water Resour. Res. 50 7662-7676.

Chattopadhyay N and Hulme M 1997 Evaporation and potential evapotranspiration in India under conditions of recent and future climate change; Agric. For. Meteorol. $8755-73$

Chen M, Xie P, Janowiak J E and Arkin P A 2002 Global land precipitation: A 50-yr monthly analysis based on gauge observations; J. Hydrometeorol. 3 249-266.

Cohen S, Ianetz A and Stanhill G 2002 Evaporative climate changes at Bet Dagan, Israel, 1964-1998; Agric. For. Meteorol. 111 83-91.

da Silva V de P R 2004 On climate variability in northeast of Brazil; J. Arid Environ. 58 575-596.

Datta R K 1993 Advances in tropical meteorology: Meteorology and national development; Proceedings of the national symposium, TROPMET-93 organized by the Indian Meteorological Society at New Delhi from March 17-19, 1993 with the theme 'Meteorology and National Development'; Article 45, pp. 375-384.

Das P K, Chakraborty A and Seshasai M V R 2014 Spatial analysis of temporal trend of rainfall and rainy days during the Indian summer monsoon season using daily gridded $\left(0.5^{\circ} \times 0.5^{\circ}\right)$ rainfall data for the period of $1971-$ 2005; Meteorol. Appl. 21 481-493.

Duncan J M A, Saikia S D, Gupta N and Biggs E M 2016 Observing climate impacts on tea yield in Assam, India; Appl. Geogr. 77 4e71.

Fan Y and Van den Dool H 2008 A global monthly land surface air temperature analysis for 1948-present; J. Geophys. Res. Atmos. 113(D1).

Fan Y and van den Dool H 2004 Climate Prediction Center global monthly soil moisture dataset at 0.5 resolution for 1948 to present; J. Geophys. Res. Atmos. 109(D10).

Fang H, Beaudoing H K, Teng W L and Vollmer B E 2009 Global Land data assimilation system (GLDAS) products, services and application from NASA hydrology data and information services center (HDISC).

Fisher J B, Tu K P and Baldocchi D D 2008 Global estimates of the land-atmosphere water flux based on monthly AVHRR and ISLSCP-II data, validated at 16 FLUXNET sites; Remote Sens. Environ. 112 901-919.

Gholkar M D, Goroshi S, Singh R P and Parihar J S 2014 Influence of agricultural developments on net primary productivity (NPP) in the semi-arid region of India: A study using GloPEM model; Int. Arch. Photogramm. Remote Sens. Spat. Inf. Sci. 40 725-732.

Goroshi S K, Singh R P, Pradhan R and Parihar J S 2015 Revisiting CASA ecosystem model for global NPP study: A new perspective; A National Seminar on Climate Change, 02-03 July 2015, DCCC, IISC, Bengaluru, India. Gupta S K, Kratz D P, Stackhouse Jr, P W and Wilber A C 2001 The Langley Parameterized Shortwave Algorithm (LPSA) for Surface Radiation Budget Studies. 1.0.

Huang J, van den Dool H M and Georgarakos K P 1996 Analysis of model-calculated soil moisture over the United States (1931-1993) and applications to long-range temperature forecasts; J. Clim. 9 1350-1362.

Jain S K and Kumar V 2012 Trend analysis of rainfall and temperature data for India. 
Jones H G 2013 Plants and Microclimate: A Quantitative Approach to Environmental Plant Physiology; Cambridge University Press.

Liu B, Xu M, Henderson M and Gong W 2004 A spatial analysis of pan evaporation trends in China, 1955-2000; J. Geophys. Res. Atmos. 109.

Mallick K, Bhattacharya B K, Chaurasia S, Dutta S, Nigam R, Mukherjee J, Banerjee S, Kar G, Rao V U M and Gadgil A S 2007 Evapotranspiration using MODIS data and limited ground observations over selected agroecosystems in India; Int. J. Remote Sens. 28 2091-2110.

Marshall M, Okuto E, Kang Y, Opiyo E and Ahmed M 2016 Global assessment of vegetation index and phenology lab (VIP) and global inventory modeling and mapping studies (GIMMS) version 3 products; Biogeosciences 13 625-639.

Meiyappan P, Roy P S, Sharma Y, Ramachandran R M, Joshi P K, DeFries R S and Jain A K 2016 Dynamics and determinants of land change in India: Integrating satellite data with village socioeconomics; Reg. Environ. Change $1-14$.

Milesi C, Samanta A, Hashimoto H, Kumar K K, Ganguly S, Thenkabail P S, Srivastava A N, Nemani R R and Myneni R B 2010 Decadal variations in NDVI and food production in India; Remote Sens. 2 758-776.

Militino A F, Ugarte M D and Pérez-Goya U 2017 Stochastic spatio-temporal models for analysing NDVI distribution of GIMMS NDVI3g images; Remote Sens. 976.

Mishra V and Lilhare R 2016 Hydrologic sensitivity of Indian sub-continental river basins to climate change; Global Planet. Change 139 78-96.

Monteith J L 1965 Evaporation and environment. The state and movement of water in living organisms; In: Symposia of the Society for Experimental Biology, Cambridge University Press, Cambridge 19 205-234.

Moonen A C, Ercoli L, Mariotti M and Masoni A 2002 Climate change in Italy indicated by agrometeorological indices over 122 years; Agric. For. Meteorol. 111 13-27.

$\mathrm{Mu}$ Q, Heinsch F A, Zhao M and Running S W 2007 Development of a global evapotranspiration algorithm based on MODIS and global meteorology data; Remote Sens.Environ. 111 519-536.

Nayak R K, Patel N R and Dadhwal V K 2013 Inter-annual variability and climate control of terrestrial net primary productivity over India; Int. J. Climatol. 33 132-142.

Oki T and Kanae S 2006 Global hydrological cycles and world water resources; Science 313 1068-1072.

Oza M and Kishtawal C M 2015 Spatio-temporal changes in temperature over India; Curr. Sci. 1091154.

Padma Kumari B and Goswami B N 2010 Seminal role of clouds on solar dimming over the Indian monsoon region; Geophys. Res. Lett. 37.

Padma Kumari B, Londhe A L, Daniel S and Jadhav D B 2007 Observational evidence of solar dimming: Offsetting surface warming over India; Geophys. Res. Lett. 34.

Padmakumari B, Jaswal A K and Goswami B N 2013 Decrease in evaporation over the Indian monsoon region: Implication on regional hydrological cycle; Clim. Change $121787-799$.

Pai D S, Sridhar L, Rajeevan M, Sreejith O P, Satbhai N S and Mukhopadhyay B 2014 Development of a new high spatial resolution $(0.25 \times 0.25)$ long period $(1901-2010)$ daily gridded rainfall dataset over India and its comparison with existing datasets over the region; Mausam 65 $1-18$.

Peterson T C, Golubev V S and Groisman P Y 1995 Evaporation losing its strength; Nature 377687.

Pingale S M, Khare D, Jat M K and Adamowski J 2014 Spatial and temporal trends of mean and extreme rainfall and temperature for the 33 urban centers of the arid and semi-arid state of Rajasthan, India; Atmos. Res. 13873 90.

Pinker R T and Laszlo I 1992 Modeling surface solar irradiance for satellite applications on a global scale; J. Appl. Meteorol. 31 194-211.

Prabakaran C, Singh C P, Panigrahy S and Parihar J S 2013 Retrieval of forest phenological parameters from remote sensing-based NDVI time-series data; Curr. Sci. 105 795-802.

Prasanna V 2014 Impact of monsoon rainfall on the total foodgrain yield over India; J. Earth Syst. Sci. 1231129 1145 .

Priestley C H B and Taylor R J 1972 On the assessment of surface heat flux and evaporation using large-scale parameters; Mon. Wea. Rev. 100 81-92.

Ramírez J A, Hobbins M T and Brown T C 2005 Observational evidence of the complementary relationship in regional evaporation lends strong support for Bouchet's hypothesis; Geophys. Res. Lett. 32.

Rodell M, Houser P R, Jambor U E A, Gottschalck J, Mitchell K, Meng C J, Arsenault K, Cosgrove B, Radakovich J and Bosilovich M 2004 The global land data assimilation system; Bull. Am. Meteorol. Soc. 85 381-394.

Roderick M L and Farquhar G D 2004 Changes in Australian pan evaporation from 1970 to 2002; Int. J. Climatol. 24 1077-1090.

Roy P S, Roy A, Joshi P K, Kale M P, Srivastava V K, Srivastava S K, Dwevidi R S, Joshi C, Behera M D and Meiyappan P 2015 Development of decadal (1985-19952005) land use and land cover database for India; Remote Sens. 7 2401-2430.

Rui $\mathrm{H}$ and Beaudoing H 2016 README; Document for Global Land Data Assimilation System, Ver 2 (GLDAS2) products, GES DISC.

Sen P K 1968 Estimates of the regression coefficient based on Kendall's tau; J. Am. Stat. Assoc. 63 1379-1389.

Singh J and Kumar M 2016 Solar radiation over four cities of India: Trend analysis using Mann-Kendall statistical test; Int. J. Renew. Energy Res. IJRER 6 1385-1395.

Singh R P, Rovshan S, Goroshi S K, Panigrahy S and Parihar J S 2011 Spatial and temporal variability of Net Primary Productivity (NPP) over terrestrial biosphere of India using NOAA-AVHRR based GloPEM model; J. Indian Soc. Remote Sens. 39345.

Soni V K, Pandithurai G and Pai D S 2012 Evaluation of long-term changes of solar radiation in India; Int. J. Climatol. 32 540-551.

Srivastava A K, Rajeevan M and Kshirsagar S R 2009 Development of a high resolution daily gridded temperature dataset (1969-2005) for the Indian region; Atmos. Sci. Lett. 10 249-254. 
State of Forest Report 1999 Forest Survey of India, Dehradun, India.

Tebakari T, Yoshitani J and Suvanpimol C 2005 Time-space trend analysis in pan evaporation over Kingdom of Thailand; J. Hydrol. Eng. 10 205-215.

Teuling A J, Hirschi M, Ohmura A, Wild M, Reichstein M, Ciais P, Buchmann N, Ammann C, Montagnani L and Richardson A D 2009 A regional perspective on trends in continental evaporation; Geophys. Res. Lett. 36.

Trenberth K E, Fasullo J T and Kiehl J 2009 Earth's global energy budget; Bull. Am. Meteorol. Soc. 90 311-323.

van den Dool H, Huang J and Fan Y 2003 Performance and analysis of the constructed analogue method applied to US soil moisture over 1981-2001; J. Geophys. Res. Atmos. 108.

Velde R, Salama M S, Pellarin T, Ofwono M, Ma Y and Su Z 2014 Long term soil moisture mapping over the Tibetan plateau using special sensor microwave/imager; Hydrol. Earth Syst. Sci. 18 1323-1337.

Willmott C J 1982 Some comments on the evaluation of model performance; Bull. Am. Meteorol. Soc. 631309 1313

Willmott C J 1981 On the validation of models; Phys. Geogr. 2 184-194.

Corresponding editor: Prashant K SRIVastava
Xiao Z, Jiang L, Zhu Z, Wang J and Du J 2016 Spatially and temporally complete satellite soil moisture data based on a data assimilation method; Remote Sens. 849.

Yanjun W, Bo L, Jianqing Z, Buda S, Yong L and Zengxin Z 2011 Relationship between potential and actual evaporation in Yangtze River Basin; Adv. Clim. Change Res. 7 1673-1719.

Zhang K, Kimball J S, Mu Q, Jones L A, Goetz S J and Running S W 2009 Satellite based analysis of northern ET trends and associated changes in the regional water balance from 1983 to 2005; J. Hydrol. 379 92-110.

Zhang K, Kimball J S, Nemani R R and Running S W 2010 A continuous satellite-derived global record of land surface evapotranspiration from 1983 to 2006; Water Resour. Res. 46.

Zhang T, Stackhouse P W, Gupta S K, Cox S J, Mikovitz J C and Hinkelman L M 2013 The validation of the GEWEX SRB surface shortwave flux data products using BSRN measurements: A systematic quality control, production and application approach; J. Quant. Spectrosc. Radiat. Transf. 122 127-140.

Zhang Y, Liu C, Tang Y and Yang Y 2007 Trends in pan evaporation and reference and actual evapotranspiration across the Tibetan Plateau; J. Geophys. Res. Atmos. 112. 